\title{
INWENTARZ KULTU MARYJNEGO W DIECEZJI TARNOWSKIEJ
}

\section{GRYWAED (pow. Nowy Targ)}

Parafia istnieje od pierwszej poł. XIV w. Kościól drewniany pod wezw. św. Marcina zbudowany w XV w. Drugi odpust obchodzi sie na uroczystość M. Boskiej Śnieżnej.

W głównym ołtarzu na zasuwie środkowej części tryptyku znajduje się obraz Maryi z Dzieciątkiem z XIX w. czczony jako M. B. Śnieżnej. Tryptyk pochodzący z pocz. XVI w. zawiera obrazy św. Marcina w środ$\mathrm{ku}$, po bokach w kwaterach przedstawienia św. Anny, św. Stanisława

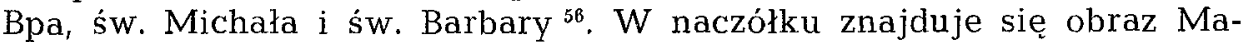
donny z Dzieciątkiem z typu Assunty apokaliptycznej. W bocznym, wczesnobarokowym ołtarzu Serca Pana Jezusa jest w górnej części Matka Boska w otoczeniu aniołów.

Polichromia z r. 1618 posiada sceny Ukrzyżowania z Maryją i św. Janem, w kasetonach na chórze M. Boskiej Bolesnej oraz cykl Męki Pańskiej. Dokładniejsza treść zostanie ustalona po ukończeniu prowadzonej już konserwacji polichromii tego najcenniejszego zabytku budownictwa drewnianego na Podhalu ${ }^{57}$.

Na ścianach kościoła wiszą obrazy: 1) wypukła rzeźba przedstawiająca Maryję z Dzieciątkiem na półksiężycu, prawdopodobnie z XVI w.; 2) malowany obraz M. B. Szkaplerznej; 3) pod dzwonnicą figura Piety; 4) w zakrystii figura Niepokalanej.

Feretrony: 1) z malowanym obrazem M. B. Niepolkalanej, po drugiej stronie - Ukrzyżowania; 2) z malowanym obrazem św. Anny i Maryi w wieku dziewczęcym, po drugiej stronie - bł. Kingi; 3) z malowanym obrazem M. B. Częstochowskiej, po drugiej stronie - św. Franciszka; 4) z malowanym obrazem M. B. Różańcowej, po drugiej stronie - $\dot{s} w$. Dominika; 5) figura Matki Boskiej wykonana w r. 1889 przez miejscowego gospodarza Jana Potaśnika; 6) ludowa figura Matki Boskiej przeniesiona w r. 1918 przez dziewczęta wsi Hałuszowa z ich dawnego parafialnego kościoła w Maniowie.

59 T, Szydłow ski: Pówiat nowotarski. W: „Katalog zabytków sztuki w Polsce". T. 1 s. 353 n. fig. 473.

57 Por. T. Hol c e row a: Polichromia kościoła w Grywałdzie. „Wiad. konserwat." $1958 \mathrm{~s}, 83-84$; J. D u t k i e w i e z: Malarstwo ścienne w budownictwie drewnianym. Tamże il. 10. 
Chorągwie i sztandary: 1) koloru białego z malowanym obrazem M. B. Częstochowskiej, po drugiej stronie - św. Józefa z Dzieciątkiem; 2) koloru zielonego z malowanym obrazem M. B. Niepokalanie Poczętej, po drugiej stronie - św. Antoniego z Dzieciątkiem; 3) koloru zielonego z malowanym obrazem M. B. Szkaplerznej, po drugiej stronie św. Michała Archanioła; 4) koloru niebieskiego z malowanym obrazem M. B. Szkaplerznej, po drugiej stronie - św. Józefa; 5) koloru czerwonego z malowanym obrazem M. B. Różańcowej, po drugiej stronie św. Jadwigi.

W Muzeum Diecezjalnym w Tarnowie znajduje się obraz z XVII w. z chorągwi przedstawiający Maryję i św. Floriana (nr inw. 802). W tymże muzeum przechowywała się do ostaniej wojny rzeźba Matki Boskiej, zrabowana przez okupacyjne władze niemieckie, dotychczas nie odnaleziona. Była to rzeźba przyścienna, wysokości $75 \mathrm{~cm}$, typu sądecko-spiskiego z lat ok. 1350/60, przedstawiająca Madonnę Tronującą z Dzieciątkiem ${ }^{58}$.

Kapliczki i figury w Grywałdzie: 1) Przy szosie Krościenko -- Nowy Targ, koło drogi skręcającej do środka wsi znajduje się obszerna (5x4 m) $\mathrm{z}$ wieżyczką murowana kaplica ${ }^{59}$, zbudowana pod koniec XIX w. przez miejscowego gospodarza Jakuba Potaśnika, zm. w $1928 \mathrm{r}$. Ołtarzyk z płaskorzeźbą M. B. Śnieżnej wykonał własnoręcznie Jan Potaśnik. $\mathrm{Z}$ budową kaplicy związana jest legenda. Jan Potaśnik wracał późnym wieczorem do Grywałdu. Na miejscu, gdzie stoi kaplica ukazała się mu Marya jako dziwnie jaśniejąca Pani i żądała, aby w tym miejscu mieszkańcy Grywałdu postawili kaplicę. Potaśnik mimo starań nie mógł tego spełnić z powodu braku odpowiednich funduszów. Z pomocą przyszedł żyd z Jazowska Adler trudniący się skupem drzewa, który, po dokonaniu korzystnych tranzakcji drzewnych z mieszkańcami Grywałdu, przeznaczył pewną sumę na jakiś zbożny cel na tejże wsi. Za owe pieniądze miano wybudować kaplicę. Potaśnik był jednak niezadowolony, że nie mógł, tak jak chciał, wyrazić w obrazie widoku Maryi z cudownego widzenia. Koło kaplicy zasadzono 4 jesiony. Jeden $\mathrm{z}$ nich został zabrany przez powódź w 1918 r. Kaplica ostała się w cudowny sposób. 2) Na realności Wojciecha Krężla stoi mniejsza murowana kapliczka $(1.90 \times 1.70 \mathrm{~m})$. W środku znajduje się obraz pochodzący z XIX w. a przedstawiający M.B. Snieżną. Legenda głosi, że na tym miejscu zamierzano pierwotnie wybudować kościól parafialny. Jednakże jakaś siła przenosiła przygotowane belki na miejsce obecnego kościoła. Za trzecim razem drzewo zostało przeniesione razem ze śpiącymi majstrami, którzy pilnowali przy-

58 Por. Dutkiewi cz: Nieznane rzeźby XIV $\longrightarrow X V$ w. na terenie Małopolski południowo-zachodniej. „Biul. Hist. Szt.” 1933 s. 253-263; M. W a li c k i: Polska sztuka gotycka s. $20 \mathrm{nr} 24$; D u t k i e w i c z: Małopolska rzeźba średniowieczna s. 129 i1. 68; D. Ka c z marz y k: Straty wojenne Polski w dziedzinie rzeźby. Warszawa 1958 s. 44 il. 23.

59 Kaplica ta była reprodukowana przez Pocztę Polska w r. 1952 na znaczku za 60 groszy. 
gotowanego budulca. Na tę pamiątkę wybudowano tutaj kapliczkę. 3) "Na Wybraństwie", na gruncie Knutelskiego (Bacy) stoi murowana kaplica, fundowana przy końcu XIX w. przez Jana Hryca, tego który spowodował umieszczenie w głównym oltarzu kościoła obecnego obrazu M. B. Śnieżnej. W kapliczce znajduje się także obraz M. B. Śnieżnej w otoczeniu figur św. Józefa i św. Antoniego. 4) „Pod Tylką", koło tartaku jest murowana kaplica, zbudowana w XIX w. przez Józefa Malika właściciela tartaku. Obecnie znajduje się pod opieką zarządu tartaku. Wewnątrz jej mieści się obraz Matki Boskiej. Opowiadają, że dawniej była kapliczka po drugiej stronie szosy ale, gdy ją zabrała woda, zbudowano obecną. 5) W ogrodzie Jana Potaśnika (Widzima) znajduje się maleńka murowana kapliczka, wybudowana z racji powodzi ok. 1834 r. na granicy oddzielającej ląd od wody. Wewnątrz posiada figurę św. Jana i dwie Matki Boskiej. Z tych ostatnich jedna sięga początkami tradycji gotyckich.

Parafianie uczęszczają z pielgrzymkami najczęściej do Kalwarii Zebrzydowskiej i Czarnego Potoka, rzadziej do Tuchowa i Częstochowy, sporadyczılie do Piekar Śląskich.

\section{GUMNISKA FOX (pow. Dębica)}

Parafia istnieje od r. 1310. Kościół drewniany pod wezw. św. Mikołaja wybudowany w XVII w. spalił się podczas działań wojennych 1944 x. Spłonęło również wyposażenie wnętrza. Nowy kościól w budowie. Tymczasowe funkcje kościoła spełnia barak przewieziony w r. 1945 z Pustkowia.

Kapliczki i figury: 1) w Gumniskach Fox fundowana w r. 1930 figura Niepokalanej; 2) w Gumniskach Fox kapliczka św. Jana Nepomucena z figurą Matki Boskiej.

Przy kościele istniał Żywy Różaniec.

Parafianie uczęszczają z pielgrzymkami do Tuchowa, Zawady, Przeczycy, Dębowca i do kaplicy we wsi Głobikowa. Zanika zwyczaj uczęszczania do Leżajska i Odporyszowa.

\section{GWOŻDZIEC (pow. Brzesko)}

Parafia istnieje od pierwszej poł. XIV w. Kościół murowany pod wezw. św. Katarzyny wybudowany w r. 1913.

W ołtarzu głównym drewniana figura Niepokalanej z $1935 \mathrm{r}$. W ołtarzu pod wezw. Matki Boskiej malowany w r. 1634 na desce obraz Madonny z Dzieciąlkiem. Przy obrazie znajduje się 16 wotów. W drugim bocznym ołtarzu znajduje się obraz M. B. z Dzieciątkiem i św. Józefem.

Kościół posiada polichromię z r. 1958 wykonaną przez art. mal. Krzyształowskiego, prof. Akademii Sztuk Plastycznych w Krakowie, w stylu nowoczesnym, ze scenami Zwiastowania, Bożego Narodzenia i M. B. Różańcowej. 
Na ścianach wiszą obrazy: 1) Matka Boska z Dzieciątkiem i św. Katarzyną (XVII w.); 2) oleodruk M. B. Tuchowskiej; 3) oleodruk M. B. Nieustającej Pomocy:

Feretrony: 1) z malowanym obrazem M. B. Niepokalanej; 2) z gipsową figurą Niepokalanej.

Chorągwie i sztandary: 1) z malowanym obrazem Serca Maryi, po drugiej stronie - św. Katarzyny z 1956 r.; 2) z malowanym obrazem M. B. z Dzieciątkiem, po drugiej stronie - św. Antoniego.

W Muzeum Diecezjalnym w Tarnowie znajduje się obraz z XVII w. Madonny z dwoma świętymi (nr inw. 308).

Kapliczki i figury: 1) w Gwoźdzcu, na realności Julii Mazgaj gipsowa figura Niepokalanej; 2) w Gwoźdzcu ṇa gruncie Franciszka Mazgaja drewniana figura Niepokalanej.

Przy kościele istnieje bractwo Różańca Żywego i Wiecznego. Parafianie uczęszczają z pielgrzymkami do Tuchowa a czasem do Kalwarii.

\section{IWKOWA (pow. Brzesko)}

Parafia istnieje od r. 1325. Kościół murowany pod wezw. Podwyższenia Krzyża zbudowany w r. 1956 na miejscu spalonego z drugiej pol. XVI w. Odpust obchodzony jest na uroczystość Nawiedzenia Maryi Panny w kościele cmentarnym w dniu 2 lipca.

W oltarzu bocznym znajduje się obraz Matki Boskiej malowany na płótnie $\mathrm{z}$ w. XVII.

Feretrony: 1) z malowanym na blasze w XIX w. obrazem M. B. Częstochowskiej, po drugiej stronie - św. Franciszka z Asyżu; 2) z malowanym na blasze obrazem Serca Matki Boskiej, po drugiej stronie Serca Pana Jezusa; 3) z malowanym na blasze obrazem M. B. z Dzieciątkiem, po drugiej stronie - Głowy Pana Jezusa otoczonej korona cierniowąi 4) z figurą drewnianą Matki Boskiej. Na białym ornacie haftowany cbraz Matki Boskiej Niepokalanie Poczętej.

Kościóick cmentarny pod wezw. Nawiedzenia Maryi. Pierwotny wzniesiony w r. 1398. Obecny drewniany, prawdopodobnie z drugiej poł. $\mathrm{XV}$ W. ${ }^{60}$

W ołtarzu głównym pod wezw. Matki Boskiej rzeźba z pocz. XVI w. przedstawiająca Matkę Boską i św. Elżbietę. Malowane tło przedstawia Ducha Sw. i tabernakulum malowane z Matką Boską i św. Janem Ewangelistą. Na tęczy krucyfiks oraz rzeźbione posągi Matki Boskiej i św. Jana Ewangelisty z końca XIV w. W oknie witrażyk z Matką Boską $\mathrm{z}$ pierwszej poł. XV w.

Kapliczki przydrożne: 1) na gruncie Jana Karwuli, „,ha Pagórku" kapliczka z malowanym obrazem Matki Boskiej Domosławickiej, z końca XIX w.; 2) na gruncie Piotra Tucznio kapliczka $z$ rzeźbioną $w$ drzewie Pieta ludową z czasu ok. $1850 \mathrm{r}$.

60 Por. Dutkiewicz: Powiat brzeski. W: „Katalog zabytków sztuki w Polsce". T, 1 s. 80 n, fig. 285 . 
Przy kościele istnieje bractwo Różańcowe.

W parafii żyje legenda odnosząca się do powstania kościoła na starym cmentarzu, będącego pierwotnie kościołem parafialnym i do witrażyka Matki Boskiej w dzisiejszym kościołku cmentarnym. W czasie powodzi (wylała rzeka Bella) woda niosła obraz Matki Boskiej, który zatrzymał się w miejscu cmentarza. Wtedy to ludzie zbudowali w tym miejscu kościół ku czci Matki Boskiej pod wezw. Nawiedzenia N. M. P. Legenda dotycząca witrażyka głosi, że w parafii żył człowiek opętany przez złego ducha, którego nie można było w żaden sposób wypędzić. Przyjechali wreszcie okoliczni kapłani, zaprowadzili opętanego przed ołtarz i odprawiali nad nim uroczyste egzorcyzmy. Wówczas diabeł opuścił opętanego i uciekł oknem wybijając z niego szybę, której odtąd nie można było wprawić, gdyż po każdym oszkleniu szyba wypadała. Wobec tego wykonano witrażyk M. $\mathrm{z}$ Dzieciątkiem, który przetrwał do dzisiejszego czasu.

Parafianie uczęszczają z pielgrzymkami do Tuchowa i Domosławic.

\section{JADOWNIKI MOKRE (pow. Dąbrowa Tarnowska)}

Parafia istnieje od r. 1952. Kościół parafialny pod wezw. Serca Maryi zbudowany w r. 1948.

W głównym ołtarzu znajduje się rzeźbiony w r. 1947 obraz Serca Maryi.

W witrażach mieszczą się przedstawienia: 1) Serca Maryi; 2) M. B. Częstochowskiej.

Feretrony: 1) płaskorzeźbiony z obrazem M. B. Częstochowskiej, po drugiej stronie - św. Antoniego; 2) płaskorzeźbiony z obrazem M. B. Nieustającej Pomocy, po drugiej stronie - św. Anny; 3) figura M. B. Niepokalanej.

Chorągwie i sztandary: 1) koloru biało-zielonego z malowanym obrazem Swiętej Rodziny, po drugiej stronie - św. Satnisława Kostki; 2) koloru czarnego z malowanym obrazem M. B. Bolesnej.

Na białym ornacie z 1954 r. malowana postać Serca Maryi z wielkiego ołtarza.

Na dzwonie umieszczono napis: „Twemu Niepokalanemu Sercu, Matko Boża - Królowo Polski, ofiarują Jadowniki Mokre w roku 1957".

Kapliczki i figury: 1) w fasadzie kościoła kamienna figura M. B. Różańcowej; 2) na polu gromadzkim, przy rozstajnej drodze kapliczka kamienna fundowana w r. 1882 przez Piotra i Marię Kumorowskich z figurą Matki Boskiej.

Przy kościele istnieje Wieczny Różaniec. Parafianie uczęszczają na odpusty do Odporyszowa.

\section{JADOWNIKI PODGÓRNE (pow. Brzesko)}

Parafia istnieje od drugiej poł. XIII w. Kościół parafialny pod wezw św. Prokopa wzniesiony w r. 1908. 
W kaplicy, w bocznym ołtarzu pod wezw. Matki Boskiej znajduje się obraz wykonany w czeskim typie Madonny Dublebskiej w otoczeniu dwu aniołów. Przemalowany i bardzo zniekształcony pochodzi z XV w. Obraz jest otoczony kultem przez miejscową ludność, o czym świadczą znajdujące się przy nim 32 wota. W bocznym ołtarzu św. Anny jest figura św. Anny z Maryją.

Feretrony: 1) z malowanym na plótnie obrazem Serca Pana Jezusa, po drugiej stronie - Serca Maryi $i_{i}$ 2) drewniana figura M. B. Różańcowej; 3) drewniana figura Niepokalanej; 4) drewniana figura Serca Maryi.

Chorągwie i sztandary: 1) koloiu białego z malowanym obrazem Zwiastowania, po drugiej stronie --. Serca Pana Jezusa; 2) koloru białego z malowanym obrazem M. B. Ezęstochowskiej, po drugiej stronie Orła Białego; 3) koloru czarnego \& malowanym obrazem M. B. Bolesnej, po drugiej stronie - Chrystusa na krzyżu.

W Jadownikach-Bocheniec znajduje się murowany kościół pod wezw. św. Anny wzniesiony przed $1732 \mathrm{r}$. W głównym ołtarzu rzeźba św. Anny Samotrzeć. Stacje Drogi Krzyżowej z XIX w.

Kapliczki i figury w Jadownikach: 1) na realności Józefa Martyny kamienna figura Matki Boskiej z XIX w.; 2) na polu Jana Szkodnego kamienna figura Chrystusa Ukrzyżowanego z Matką Boską pochodzącą z XIX w.; 3) na gruncie Józefa Migały kamienna figura Matki Boskiej z XVIII w.; 4) na posiadłości Jakuba Martyny nad studzienką kamienna figura św. Anny i Maryi z XVIII w.; 5) kamienna figura Matki Boskiej z XIX w.; 6) kamienna figura Maryi ze Swiętymi; 7) na polu Władysława Sali kapliczka z kamienną figurą Chrystusa Ukrzyżowanego i M. B. Bolesnej; 8) na posiadłości rodziny Chuchrów kamienna figura Matki Boskiej z Dzieciątkiem z r. 1888; 9) na gruncie Stanisława Gurgula kamienna figura Matki Boskiej; 10) na realności rodziny Bartoszów kamienna figura Matki Boskiej.

Parafianie uczęszczają z pielgrzymkami najwięcej do Tuchowa, poza tym do Odporyszowa, Bochni i Porąbki Uszewskiej.

\section{JAKUBKOWICE (pow. Nowy Sącz)}

Parafia istnieje od r. 1325. Kościół drewniany pod wezw. św. Piotra i Pawła z r. 1739.

W ołtarzu glównym z epoki Rejencji płaskorzeżba z krucyfiksem i figurą Maryi oraz św. Jana $z$ pierwszej poł. XVIII w. W rokokowym ołtarzu bocznym pod wezw. Matki Boskiej obraz malowany na desce typu Piekarskiej z XVI w. przykryty sukienką z XVIII w., czczony w parafii jako M. B. Pocieszenia. Przy obrazie znajdują się dwie gabloty z 25 wotami. W predelli ołtarza oleodrukowy obraz M. B. Bolesnej. W drugim bocznym ołtarzu pod wezw. M. B. Różańcowej płaskorzeźbiony obrảz tego tytułu z r. 1826. 
W polichromii na plafonie scena Wniebowzięcia. lesnej.

W kruchcie zawieszony na ścianie oleodrukowy obraz M. B. Bo-

Feretrony: 1) z malowanym na blasze obrazem Niepokalanej typu Murilla; 2) malowany na blasze obraz M. B. Nieustającej Pomocy; 3) malowany na papierze za szkłem obraz M. B. Bolesnej; 4) drewniana figura M. B. z Dzieciątkiem.

Chorągwie i sztandary: 1) koloru zielonego z malowanym obrazem M. B. Częstochowskiej, po drugiej stronie - Serca Pana Jezusa; 2) koloru popielatego z malowanym obrazem Nieustającej Pomocy, po drugiej stronie - św. Michała; 3) koloru czerwonego z malowanym obrazem Serca Maryi, po drugiej stronie - Serca Pana Jezusa; 4) koloru niebieskiego $\mathrm{z}$ malowanym obrazem Serca Maryi, po drugiej stronie młodego Tobiasza; 5) koloru niebieskiego z malowanym obrazem $\mathrm{M}$. B. z Lourdes, po drugiej stronie - Chrystusa Króla; 6) koloru czerwonego $\mathrm{z}$ haftowanym obrazem M. B. Częstochowskiej, po drugiej stronie św. Stanisława Kostki; 7) koloru czarnego z malowanym obrazem M. B. Róźańcowej.

Na białym ornacie z 1956 r. z przodu malowany obraz Ziastowania, z tyłu Niepokalanego Poczęcia. Na dzwonie ryngraf Matki Boskiej oraz napis: „Królowo Polski módl się za nami 1956".

Kaplice mszalne: 1) W Żbikowcach na dawnym cmentarzu cholerycznym wybudowano kaplicę w r. 1868, w której odprawiają się msze św. w niedziele, święta i środy od maja do października. W kaplicy ołtarz o tradycjach klasycystycznych $\mathrm{z}$ obrazem M. B. Bolesnej "it. Przy obrazie wota $\mathrm{z}$ serc, korali, ryngrafów, medalionów, paciorków. Z racji tego obrazu kaplica posiadała w r. 1954 przywilej sanktuarium maryjnego. 2) W Bilsku "Na Marsztynówce" kaplica z malowanym na blasze obrazem M. B. Nieustającej Pomocy.

Kapliczki i figury: 1) w Łososinie Dolnej kapliczka Matki Boskiej fundowana w r. 1918 na podziękowanie za odzyskanie wolności; 2) w Michalczowej figura Matki Boskiej w gablocie wisząca na krzyżu; 3) na realności Jana Borka figura M. Boskiej z Lourdes; 4) na polu Jana Maciasa kamienna figura M. B. Królowej Polski.

Przy kościele istnieje Żywy Różaniec. Parafianie uczęszczają z pielgrzymkami do Kalwarii Zebrzydowskiej na Wielki Piątek i 15 sierpnia, czasem do Tuchowa.

\section{JAMY (pow. Mielec)}

Parafia istnieje od r. 1925. Kościół parafialny pod wezw. św. Augustyna zbudowany w r. 1916. Od r. 1916 do 1925 był on kościołem filialnym w parafii Zgórsko.

61 Por, A. Misiąg-B o cheńska: Powiat nowosądecki. W: „Katalog zabytków sztuki w Polsce". T. 1 s. 343. 
W ołtarzu bocznym pod wezw. św. Augustyna znajduje się obraz przedstawiający Maryję z Dzieciątkiem i klęczącym przed nią św. Augustynem. W ołtarzu bocznym pod wezw. Matki Bożej umieszczona jest gipsowa figura Wniebowziętej, którą na miesiąc październik zasuwa się obrazem M. B. Różańcowej. Obraz malowany na płótnie prawdopodobnie w XIX w., dwukrotnie odnawiany, drugi raz przemalowany i powiększony. W ołtarzu bocznym pod wezw. Pana Jezusa Ukrzyżowanego umieszczony jest oleodrukowy obraz M. B. Bolesnej.

Na ścianach kościoła wiszą: 1) oleodrukowy obraz M. B. Tuchowskiej; 2) malowany na płótnie obraz M. B. Niepokalanie Poczętej; 3) malowany na płótnie obraz Maryi z napisem: „Pod Twoją obronę uciekamy się”; 4) oleodrukowy obraz M. B. Bolesnej z napisem: „Pamiątka koronacji cudownego obrazu M. B. Bolesnej w klasztorze oo. Franciszkanów w Krakowie dnia 20.IX.1908 r."

Feretrony: 1) drewniana figura M. B. Pocieszenia; 2) płaskorzeźbiony obraz Niepokalanej, po drugiej stronie - św. Antoniego, wykonany we Włoszech na specjalne zamówienie parafian.

Chorągwie i sztandary: 1) koloru biało-niebieskiego z malowanym obrazem M. B. z Lourdes, po drugiej stronie - Pana Jezusa Miłosiernego, z r. 1951 r.; 2) koloru niebieskiego z malowanym obrazem Serca Maryi Panny, po drugiej stronie - M. B. z Dzieciątkiem, p̀zzed którą klęczy św. Alojzy, z r. 1950; 3) koloru zielonego z malowanym obrazem M. B. Częstochowskiej, po drugiej stronie godło państwowe, z r. 1949; 4) koloru czarnego z malowanym obrazem M. B. Szkaplerznej unoszącej się nad czyśćcem, po drugiej stronie - Pana Jezusa Ukrzyżowanego, z r. 1948.

Kapliczki i figury: 1) W Jamach, blisko kościoła kapliczka z porcelanową figurą Serca Maryi, fundowana w r. 1886 przez Franciszka Tomczyka. Pierwotnie wyposażona była $\mathrm{w}$ szereg małych porcelanowych i szklanych figurek Maryi. Obecnie znajduje się w niej tylko ołtarzyk i 4 obrazy. Pozostałe obrazy i figurki uległy zniszczeniu podczas ostatniej wojny. Dwa z nich przedstawiają M. B. Częstochowską i 15 tajemnic różańcowych naklejonych na jeden obraz. 2) Na realności Władysława Szeligi w Małcu, obok lasu kapliczka z oleodrukowym obrazem przedstawiającym scenę koronowania Maryi fundowana w r. 1910. 3) W Małcu, na skrzyżowaniu gościńców Radomyśl-Radgoszcz stała duża, najstarsza na terenie parafii kapliczka prawdopodobnie z obrazem M. B. Kalwaryjskiej. Obraz ten miał cieszyć się specjalnym kultem u miejscowej ludności. Przy niej zatrzymywały się grupy pątników śpieszących do Odporyszowa, śpiewając pieśni maryjne. Kapliczka uległa całkowitemu zniszczeniu w czasie minionej wojny.

Dawniej istniały przy kościele dwa bractwa: Żywego Różańca i Matki Boskiej Szkaplerznej.

Parafianie uczęszczają na odpusty do Odporyszowa. Dawniej uczęszczano również do Tuchowa. Mieszkańcy Małca często gromadzą się 
przed kapliczką z krzyżem i obrazem Chrystusa Cierpiącego, śpiewając pieśni maryjne, litanię i antyfony.

86. JANOWICE (pow. Tarnów)

Parafia istnieje od r. 1911. Kościól drewniany pod wezw. Podwyższenia Krzyża Św. zbudowany w r. 1909.

W ołtarzu bocznym pod wezw. Maryi znajduje się figura M. B. z Dzieciątkiem wykonana z gipsu w r. 1875 we Francji.

Na ścianach kościoła znajdują się: 1) malowany na blasze obraz Matki Boskiej Wspomożenia. Wiernych; 2) malowany na płótnie obraz M. B. Bolesnej.

We feretronie drewniana figura M. B. Różańcowej.

Kapliczki i figury: 1) przy szosie do Tarnowa kamienna figura M. B. z Dzieciątkiem z XIX w.; 2) w Janowicach gipsowa figura na kamiennym cokole M. B. Niepokalanie Poczętej; 3) w Janowicach dwie małe figurki Matki Boskiej na postumencie drewnianym.

Przy kościele istnieje bractwo Żywego Różańca. Parafianie uczęszczają na odpusty do Tuchowa.

\section{JASIENNA (pow. Nowy Sącz)}

Parafia istnieje od r. 1932. Kościół drewniany pod wezw. Imienia Maryi Panny zbudowano w r. 1925.

W głównym ołtarzu pod wezw. Matki Boskiej znajduje się malowany na desce obraz M. B. Częstochowskiej. W niesiącu maju wstawia się do bocznego oitarza gipsową figurę Maryi.

W r. 1955 kościół otrzymał polichromię z przedstawieniami Zwiastowania N. Maryi.w towarzystwie św. Anny.

Na chórze zawieszono oleodrukowy obraz M. B. z Dzieciątkiem.

Feretrony: 1) z malowanym na desce obrazem M. B. Nieustającej Pomocy, po drugiej stronie - Madonny z Dzieciątkiem; 2) gipsowa fi.gura Maryi Niepokalanie Poczętej.

Chorągwie i sztandary: 1) koloru biało-czerwonego z malowanym obrazem Swiętej Rodziny, po drugiej stronie - św. Antoniego Opata; 2) koloru czerwonego z malowanym obrazem M. B. Częstochowskiej; 3) koloru biało-zielonego z malowanym obrazem M. B. Niepokalanie Poczętej, po drugiej stronie - św. Józefa; 4) koloru białego z haftowanym obrazem M. B. Częstochowskiej z napisem: "Pod Twoją obronę uciekamy się".

W Muzeum Diecezjalnym w Tarnowie znajduje się malowany na płótnie obraz M. B. Bolesnej pochodzący z XVIII w. (nr inw. 1047).

Przy kościele istnieją bractwa Milicji Niepokalanej, Wiecznego i Żywego Różańca oraz Szkaplerza Św.

Parafianie uczęszczają na odpusty do Tuchowa na dzień 8 września i w oktawie. Poza tym odbywają chętnie pielgrzymki do Dębowcá i Częstochowy. 


\section{JASIEŃ (pow. Brzesko)}

Parafia istnieje od r. 1325. Kościół murowany pod wezw. Wniebowzięcia Maryi Panny zbudowany w r. 1436 przez Spytka z Melsztyna ${ }^{62}$.

W ołtarzu głównym pod wezw. M. Boskiej umieszczony jest malowany na płótnie obraz Wniebowzięcia Maryi Panny oraz płaskorzeźba Niepokalanie Poczętej. W ołtarzu bocznym pod wezw. M. B. Szkaplerznej znajdują się dwa obrazy: 1) malowany na płótnie M. B. Szkaplerznej z XVIII w. i 2) obraz malowany na płótnie M. B. Róźańcowej oraz figura gipsowa M. B. z Dzieciątkiem. W ołtarzu bocznỵm pod wezw. św. Józefa jest obraz malowany na płótnie przedstawiający Swiętą Rodzinę.

Kościół w r. 1925 otrzymał polichromię i posiada sceny maryjne: Zwiastowania, Nawiedzenia, Narodzenia Pana Jezusa, Ofiarowania, Wniebowzięcia i Ukoronowania Maryi.

Feretrony: 1) gipsowa figura Serca Maryi; 2) drewniana figura M. B. z Lourdes; 3) malowany na płótnie obraz M. B. z Dzieciątkiem, po drugiej stronie - Swiętej Trójcy; 4) oleodrukowy obraz M. B. Częstochowskiej, po drugiej stronie - M. B. Nieustającej Pomocy; 5) oleodrukowy obraz M. B. Częstochowskiej, po drugiej stronie - Madonny z Dzieciątkiem; 6) malowany na płótnie obraz M. B. Różańcowej, po druglej stronie - św. Józefa z młodzieńczym Jezusem.

Sztandary i chorągwie: 1) koloru zielonego z malowanym obrazem M. B. Niepokalanie Poczętej, po drugiej stronie Anioła Stróża z małym dzieckiem; 2) koloru czerwonego z malowanym obrazem Serca Maryi, po drugiej stronie - Serca Pana Jezusa; 3) koloru czerwonego z malowanym obrazem M. B. Częstochowskiej, po drugiej stronie - Serca Jezusowego; 4) koloru czarnego z malowanym obrazem M. B. Różańcowej.

Na białym ornacie obraz Matki Boskiej. Dwa dzwony posiadają imię Maryi: 1) dzwon średni z wizerunkiem Niepokalanej i napisem: "Matka Boska Niepokalanie Poczęta - 1922"; 2) dzwon duży z wizerunkiem Matki Boskiej z Dzieciątkiem.

Na cmentarzu znajduje się kaplica mszalna zbudowana $\mathrm{w}$ w. XIX. Jeden z witraży przedstawia M. B. Tuchowską.

Kapliczki i figury: 1) obok ogrodu plebańskiego kamienna kapliczka z figurą M. B. Różańcowej fundowana przez Agnieszkę i Marcina Dudów; 2) w pobliżu kościoła drewniana kapliczka z obrazem M. B. z Dzieciątkiem. Oprócz obrazu jest w niej figurka Maryi przeniesiona z kościoła parafialnego; 3) w ogrodzie Izy Cisakowej stoi figura kamienna M.B. Różańcowej, fundacji Michała Libery i jego żony Katarzyny z r. 1860 , Na cokole są płaskorzeźby, z kiórych jedna przedstawia koronację Matki Boskiej; 4) na realności rodziny Łasków kapliczka murowana w rodzaju

62 Parafia należy do najstarszych kościołów posiadających tytuł Wniebowzięcia Maryi. Por. Ks. B. K u m or: Najśw. Maryja Panna jako patronka kościołów parafialnych w archidiakonacie sądeckim, wojnickim j prepozyturze tarnowskiej (do końca XVI w.). „Nasza Przeszł.” 9: 1959 s. 362. 
pomnika, fundowana przez Franciszka i Salomeę Kądziołków w r. 1887. Na jej szczycie krzyż, pod krzyżem figura Matki Boskiej, na cokole płaskorzeźba przedstawiająca Wniebowzięce. 5) w Grędach Szczepanowskich kamienna figura M. B. z Dzieciątkiem fundowana przez Mariannę i Błażeja Kołodziejów; 6) w Kopalinach kamienna kapliczka z figurą M. Boskiej, fundowana przez rodzinę Królów w r. 1936; 7) w Nowej Wsi na realności Jakuba Biela kamienny krzyż; na cokole w niszy umieszczona jest gipsowa figurka Niepokalanie Poczętej; 8) w Pomianowie na gruncie Władysława Piecha kamienny krzyż, fundacji Floriana i Salomei Niedzielskich z r. 1905. W cokole nisza z figurą M. B. Różańcowej.

Przy kościele jest bractwo Różańcowe. Na odpusty parafianie najchęiniej uczęszczają do Tuchowa a oprócz tego do Bochni i Okulic.

\section{JASTRZAZBKA NOWA (pow. Tarnów)}

Parafia istnieje od 1906 r. Kościól parafialny pod wezw. Serca Pana Jezusa zbudowany w r. 1903.

W ołtarzu głównym nad obrazem Serca Pana Jezusa znajduje się figura Matki Boskiej.

W bocznym ołtarzu pod wezw. Matki Boskiej drewniana figura M. B. Różańcowej z $1905 \mathrm{r}$. W drugim bocznym ołtarzu - malowany na blasze obraz M. B. Nieustającej Pomocy z 1905 r.

Feretrony: 1) drewniana figura M. B. Różańcowej wykonana w r. 1907; 2) drewniana figura Niepokalanej również z tego czasu.

Na sztandarze malowany obraz M. B. Częstochowskiej, po drugiej stronie - Orła Polskiego.

Na ornacie z r. 1951 haftowany obraz M. B. Częstochowskiej.

Kapliczki i figury: 1) w Jastrząbce Nowej "na Wesołej" koło drogi znajduje się figura Matki Boskiej posiadająca na postumencie we wnękach drewniane figurki święlych; 2) w Jastrząbce Nowej gipsowa figura Matki Boskiej; 3) Jaworniku Nowym, koło cmentarza kapliczka z XIX w. przyozdobiona wieżyczką. Wewnątrz rzeźba Matki Boskiej z Dzieciątkiem, typu krakowskiego, pochodzạca z ok. $1440 \mathrm{r}{ }^{63}$ Ludność jest bardzo przywiązana do tej figury. Opowiadają jakoby figurę miała przynieść woda podczas powodzi. Chciano ją przewieźć do kościoła w Lisiej Górze, lecz nawet dwie pary wołów nie zdołały jej ruszyć z miejsca. Wobec tego wybudowano dla niej tutaj kaplicę. Gromadzi się w niej ludność na tradycyjne majówki.

Przy kościele istnieje bractwo Żywego Różańca. Parafianie uczęszczają z pielgrzymkami do Tuchowa.

63 Por. D utki ew i c z: Małopolska rzeźba średniowieczna s. 124 il. 59; t.e ṅ̇e: Powiat tarnowski. W: „Katalog zabytków sztuki w Polsce”. T. 1 s. 428 fig. 606 . 
Parafia istnieje od r. 1581. Kościół parafialny pod wezw. św. Piotra i Pawła zbudowany w r. 1934.

W ołtarzu głównym pod wezw. tychże apostołów znajduje się płaskorzeźbiony w drzewie obraz Matki Boskiej Pocieszenid. W ołtarzu bocznym pod tytułem Matki Bożej umieszczona jest gipsowa figura, przedstawiająca M. B. z Lourdes, obraz Matki Boskiej Różańcowej malowany na płótnie w okresie powojennym oraz w górnej części obraz przedstawiający Wniebowzięcie Maryi, malowany na plótnie w latach powojennych. W drugim ołtarzu bocznym znajduje się obraz M. B. Nieustającej Pomocy.

Na ścianie zawieszony jest obraz M. B. Częstochowskiej.

Feretrony: 1) drewniana figura M. B z Dzieciątkiem; 2) gipsowa figura M. Boskiej; 3) malowany obraz na blasze M. B. Nieustającej Po mocy, po drugiej stronie - św. Antoniego z Dzieciątkiem; 4) malowany na płótnie obraz M. B. Różańcowej, po drugiej stronie Maryi z Dzieciątkiem.

$\mathrm{Na}$ dzwonie znajdują się napisy: "Imię moje Maryja Będę nawoływać Polaków do zgody. Ulany w 1952 r.".

Kapliczki i figury: 1) na realności Józefa Wójcika Arewniana figura zawieszona na drzewie; 2) w środku wsi, na polu. gromadzkim murowana kapliczka z drewnianą figurą M. Boskiej i Dzieciącka oraz malowanym obrazem na płótnie przedstawiającym Wniebowzięcie; 3) na polu Marii Drożdż gipsowa figura Matki Boskiej z Lourdes; 4) ua polu Marii Borek kamienna figura M. B. Niepokalanie Poczętej.

Przy kościele istnieje bractwo Różańca Św. Najczęściej uczęszczänym miejscem odpustowym jest Tuchów, w dalszej kolejności idą Częstuchowa i Odporyszów.

\section{JASTRZĘBIA (pow. Tarnów)}

Parafia istnieje od drugiej poł. XIV w. Drewniany kościół parafialny pod wezw. św. Bartłomieja wybudowany przed r. 1529.

W bocznym oltarzu znajduje się malowany na płótnie obraz Matki Boskiej z Dzieciątkiem, pochodzący z XVII w., czczony pod imieniem Wspomożenia Wiernych. Obraz pokryty sukienką.

W przedsionku kościoła znajduje się duży obraz Wniebowzięcia z XVII w., malowany na płótnie. Wewnątrz kościoła wiszą dwa oleodrukowe obrazy M. B. Nieustającej Pomocy i M. B. Tuchowskiej.

Feretrony: 1) z malowanym na papierze obrazem M. B. Różańcowej, po drugiej stronie - M. B. Wybawiającej dusze z czyśćca; 2) z malowanym na blasze obrazem Serca Maryi, po drugiej stronie - Serca Pana Jezusa; 3) drewniana figura Niepokalanej.

Chorągwie i sztandary: 1) koloru czerwonego z malowanym obrazem Wniebowzięcia; 2) koloru różowego z malowanym obrazem Boże- 
go Narodzenia, po drugiej stronie - Pokłonu Trzech Mędrców; 3) koloru czarnego $z$ malowanym obrazem Maryi podającej szkaplerz duszom czyśćcowym, po drugiej stronie - M. B. z Dzieciątkiem.

Kapliczki i figury: 1) w Jastrzębi „na Budzyniu” murowana kaplica mająca we whęce obraz M. B. Bolesnej; 2) przy drodze, "na Łazy" kapliczka z oleodrukowym obrazem Niepokalanej; 3) w gromadzie Kąśna Dolna grota $z$ figurą M. B. z Lourdes.

Przy kościele istnieje bractwo Wiecznego i Żywego Różańca.

Parafianie uczęszczają z pielgrzymkami najliczniej do pobliskiego Tuchowa, rzadziej do Kalwarii Zebrzydowskiej i Bruśnika.

\section{JAŚŁANY (pow. Mielec)}

Parafia istnieje od r. 1795. Kościół parafialny pod wezw. Niepokalanego Poczęcia zbudowany w r. 1903.

W ołtarzu głównym poświęconym Maryi umieszczona jest drewniana figura M. B. Niepokalanie Poczętej z $1904 \mathrm{r}$. Z racji tej figury kościół posiadał w r. 1954 przywilej sanktuarium maryjnego.

W r. 1904 kościól otrzymał polichromię ze scenami Bożego Narodzenia i Wniebowzięcia oraz napisami na tęczy: "Wieża Dawidowa", "Wieża z kości słoniowej", "Dom złoty“, "Arka Przymierza”.

Na ścianie zawieszony jest oleodrukowy obraz M. B. Nieustającej Fomocy z r. 1952.

Feretrony: 1) malowany na płótnie obraz Wniebowzięcia, po drugiej stronie - Przemienienia Pańskiego; 2) oleodrukowy obraz Serca Maryi, po drugiej stronie - Serca Jezusowego; 3) drewniana figura Niepokalanej; 4) drewniana figura Maryi z Lourdes; 5) drewniana figura Serca Maryi Panny.

Chorągwie i sztandary: 1) z malowanym na plótnie obrazem M. B. Nieustającej Pomocy, po drugiej stronie - św. Antoniego Padewskiego; 2) koloru zielonego z malowanym obrazem M. B. Częstochowskiej, po drugiej stronie - haftowanego Orła Białego; 3) koloru białego z malowanym obrazem M. B. Różańcowej, z drugiej strony - św. Wojciecha; 4) koloru czerwonego $z$ malowanym obrazem M. B. Niepokalanie Poczętej, po drugiej stronie - monogramem Maryi.

Kapliczki i figury: 1) w Jaślanach, na realności Tomasza Rzeźnika, kamienna figura Niepokalanej; 2) tamże, na gruncie Andrzeja Reca, kamienna figura M. B. Niepokalanie Poczętej.

Przy kościele istnieje bractwo Żywego i Wiecznego Różańca. Parafianie najczęściej uczęszczają z pielgrzymkami do Leżajskła i Kalwarii Ze:brzydowskiej a pojedyńczo do Częstochowy.

\section{JAWORZNA (pow. Limanowa)}

Parafia istnieje od r. 1933. Kościół parafialny pod weziw. Przemienienia Pańskiego wzuiesiony został w 1932 r. 
W ołtarzu głównym znajduje się obraz Wniebowzięcia Maryi Panay malowany na płótnie w r. 1941. W bocznym ołtarzu pod tytułem Matki Boskiej umieszczono obraz M. B. Nieustającej Pomocy, malowany na płótnie przez ks. Adama Stachonia w r. 1943. Przy obrazie jest 12 wotów.

$\mathrm{Na}$ ścianie zawieszony jest oleodrukowy obraz M.B. Częstochowskiej.

Feretrony: 1) gipsowa figura M. B. Niepokalanie Poczęlej, fundowana przez Katarzyne Joniec, była przed 1943 r. w ołtarzu Matki Bożej; 2) gipsowa figura M. B. Różańcowej; 3) pałskorzeżbiony obraz Serca Marỵi, po drugiej stronie - Serca Jezusa.

$\mathrm{Na}$ jednej chorągwi koloru białego z r. 1934 malowany na płótnie obiaz Serca Maryi, po drugiej stronie - Serca Pana Jezusa.

Kaplice i figury: 1) w Jaworznej, koło kościoła gipsowa figura M. B. Bolesnej fundowana w r. 1932 przez Stanisława Oleksego; 2) w Jaworznej, na polu Józefa Wróbla gipsowa figura M. B. Majowej wykonana przez Józefa Augustyna w r. 1940; 3) w Jaworznej, na realności Mjchała Pasionka figura M. B. Bolesnej wykonana z drzewa przez Stanisława Augustyna; 4) przy drodze na Jaworznę Górną, na polu Władysława Króla figura M. B. z Dzieciątkiem wykonana z kamienia przez Józefa Bukowca w r. 1878, fundacji Michała i Reginy Urygów; 5) w Jaworznej, na polu Michała Dudka znajduje się krzyż a pod nim rzeżbiona w końcu XIX w. przez Józefa Dudka figura Maryi; 6) na "Antosiakówce“, w kapliczce na polu Józefa Filipka, gipsowa figura M. B. Różańcowej wykonaıı przez Wojciecha Samka z Bochni w r. 1910, fundowana przez Jana i Karolinę Stachów; 7) w Żmiącej, na gruncie Walentego Dudka figura M. B. Niepokalanej wykonana z gipsu przez właściciela; 8) w Żmiącej, na polu Walentego Filipka kapliczka z malowanym na papierze obrazem M. B. Nieustającej Pomocy, wykonanym przez Stanisława Augustyna w $1931 \mathrm{r}$.

Przy kościele istnieje bractwo Żywego Różańca.

Parafianie odbywają pielgrzymki do Częstochowy, Kalwarii Zebrzycowskiej (najczęściej) i Pasierbca.

\section{JAZOWSKO (pow. Nowy Sącz)}

Parafia istnieje od drugiej poł. XIII $w^{64}$ Kościół parafialny pod wezw. Narodzenia Panny Maryi zbudowany w r. 1726. Główny odpust obchodzi się 8 września a drugi na Matkę Boską Szkaplerzną.

W ołtarzu głównym umieszczony jest obraz M. B. Szkaplerznej malowany na desce w poł XVII w. Obraz słynie łaskami, o czym świadczy ok. 100 wotów. Z racji tegoż kościół posiadał w r. 1954 przywilej sanktuarium maryjnego. W ołtarzu bocznym ku czci Maryi znajduje się obraz Matki Boskiej Rúżańcowej. W drugim bocznym ołtarzu pod wezwaniem Matki Boskiej Bolesnej mieści się rzeźba przedstawiająca Pietę.

64 Ks. B. K u m o r, jw, s, 364. 
Kościół otrzymał polichromię w r. 1900. Na ścianie prezbiterium przedstawione jest Zwiastowanie, na sklepieniu Wniebowzięcie a na bocznej ścianie Sw. Rodzina. W kościele jest obraz przedstawiający Narodzenie Maryi Panny, pochodzący z pocz. XVII w. Dawniej byl w głównym ołtarzu ${ }^{65}$ i obecnie bywa tam czasem wstawiany.

Feretrony: 1) malowany na płótnie obraz M. B. Częstochowskiej, po drugiej stronie - Chrystus w Ogrójcu; 2) oleodrukowy obraz Wniebowzięcia, po drugiej stronie - Ukoronowania Maryi; 3) oleodrukowy obraz Serca Maryi, po drugiej stronie - Serca Pana Jezusa; 4) oleodrukowy obraz M. B. Nieustającej Pomocy, po drugiej stronie - Jezusa w cierniowej koronie; 5) malowany na desce obraz M. B. Różańcowej, po drugiej stronie - św. Józefa; 6) drewniana figura Madonny z Dzieciątkiem.

Chorągwie i sztandary: 1) koloru czerwonego z malowanym obrazem M. B. Różańcowej, po drugiej stronie - św. Józefa z Dzieciątkiem; 2) koloru zielonego z malowanym obrazem M. B. Szkaplerznej, po drugiej stronie - św. Stanisława Kostki; 3) koloru białego z malowanym obrazem Serca Maryi, po drugiej stronie - Serca Jezusowego; 4) koloru czarnego z malowanym obrazem M. B. Bolesnej, po drugiej stronie Pana Jezusa na krzyżu.

Na białym ornacie z r. 1955 haftowany obraz Niepokalanego Poczęcia.

W murze otaczającym kościół znajduje się ludowy obraz M. B. Szkaplerznej, prawdopodobnie $\mathrm{z}$ feretronów, albowiem na drugiej jego stronie widnieje obraz Pana Jezusa na krzyżu i dusze w czyśćcu.

W Brzynie stoi drewniana kaplica pod wezw. św. Andrzeja Boboli. fundowana po kanonizacji świętego staraniem ówczesnego proboszcza w Jazowsku ks. dra Juliana Piskorza. W ołtarzu znajduje się obraz M. B. Różańcowej w otoczeniu obrazów M. B. Częstochowskiej i św. Józefa. Wewnątrz są stacje Drogi Krzyżowej malowane w r. 1952 przez ludowego malarza Antoniego Dzika z Radczy.

Przy kościele jest bractwo Żywego Różańca. Istnieje też od dawna bractwo Szkaplerza Sw. Już w r. 1700 Józef Karol Lubomirski ustanowił tu wieczystą fundację dla praktyk religijnych związanych $\mathrm{z}$ bractwem i kultem M. B. Szkaplerznej ${ }^{66}$.

Parafianie uczęszczają z pielgrzymkami do Kalwarii Zebrzydowskiej, Czarnego Potoku, rzadziej do Tuchowa i Częstochowy. Poza tym uważają swój obraz jako łaskami słynący. Jeszcze w r. 1938 przybyła tutaj pielgrzymka ze Słowacji.

95. JODŁOWA (pow. Jasło)

Parafia istnieje od r. 1359. Kościół parafialny pod wezw. Przeniesienia Relikwi św. Stanisława zbudowany w r. 1676. Odpust ku czci Maryi obchodzony jest na Matkę Boską Bolesną.

65 M is i ą g - B ocheńska, jw. s. 300 .

66 Akta fundacji mszalnych par. Jazowsko. (Arch. Diec, w Tarnowie). 
W ołtarzu boczllym poświęconym Maryi znajduje się drewniana figura M. B. z Dzieciątkiem, zasuwana na miesiąc wrzesień obrazem M. Boskiej.

Na ścianie zawieszono malowany na płótnie obraz Matki Boskiej z Dzieciątkiem z XIX w.

$\mathrm{Na}$ żyrandolu z blachy w kształcie lodzi z kulą ziemską umieszczona jest postać M. B. Różańcowej z napisein: „Jodłowiacy z Ameryki swojej Najświętszej Matce ofiarują 1906“. Wokoło łodzi napis: „Maryo Matko Nasza, Królowo Korony Polskiej, módl się za nami".

Feretrony: 1) drewniana figura M. B. z Lourdes; 2) drewniana figura Niepokalanej; 3) feretron z 1872 r., który posiada malowany na płótıie obraz Wniebowzięcia Maryi Panny z piętnastoma innymi obrazkami, przedstawiającymi tajemnice Różańca Swiętego; po drugiej stronie obraz M. B. Częstochowskiej z piętnastoma obrazkami wyobrażającymi różnych świętych; 4) malowany obraz M. B. Różańcowej, z drugiej strony - św. Stanisława i św. Klary; 5) feretron z malowanym obrazem św. Anny i Maryi, po drugiej stronie - Anioła Stróża.

Chorągwie i sztandary: 1) koloru czerwonego $z$ malowanym w XVIII w. obrazem M. B. Różańcowej, po drugiej stronie -- św. Stanisława Bpa; 2) koloru zielonego z malowanym obrazem Serca Maryi, po drugiej stronie - Najśw. Serca Jezusa; 3) koloru niebieskiego z malowanym obrazem Wniebowzięcia Maryi Panny, po drugiej stronie św. Józefa; 4) Sztandar miejscowej straży pożarnej koloru czerwonego z malowanym obrazem M. B. Czestochowskiej, po drugiej stronie św. Floriana; 5) koloru czerwono-białego z malowanym obrazem M. B. Częstochowskiej, po drugiej stronie haftowany Orzeł $w$ koronie oraz napis: „Koło Młodzieży Jodłowa Dolna".

W kościele ponadto znajduje się ornat $\mathrm{z}$ haftowanym obrazem $\mathrm{M}$. B. Niepokalanie Poczetej, puszka z wizerunkiem Serca Maryi oraz dzwon $z$ podobizną M. B. Bolesnej.

Kaplice mszalne: 1) W Dębowej pod wezw. Niepokalanego Poczęcia. Na zewnątrz w niszy znajduje sję figura Matki Boskiej pod krzyżem z XIX w. Wewnątrz ołtarz z drewnianą figurą Maryi Niepokalanej. Przy figurze 5 wotów. W kaplicy widać 4 obrazy maryjne: $1^{0}$ oleodrukowy obraz Matki Boskiej Tuchowskiej, $2^{0}$ obraz M. B. Nieustającej Pomocy, $3^{n}$ malowany na płótnie obraz M. B. Częstochowskiej i $4^{0}$ malowany obraz z podpisem: "Figura cudownej Matki Boskiej w kościele bernardynów w Rzeszowie, ukoronowana w 1763 r.". 2) W Jodłowej-Nagórze, na polu Józefa Kwiatkowskiego stoi kaplica mszalna z tryptykowym ołtarzem przedstawiającym w części środkowej Pana Jezusa w cierniowej koronie i Matkę Boską Bolesną. 3) Na cmentarzu w Jodłowej jest kaplica pod tytułem św. Józefa a w jej głównym ołtarzu obraz M. B. Częstochowskiej.

Kapliczki i figury: 1) na polu rodziny Dzierwów zbudowana w r. 1880 kapliczka z ołtarzykiem, w którym umieszczona jest gipsowa figura Nie- 
pokalanej; 2) na realności Edwarda Kowalskiego kapliczka z obrazem M. B. Czestochowskiej malowanym na płótnie; 3) drewniana kapliczka z r. 1910 z figurą N. M.P. Niepokalanie Poczętej.

Przy kościele istnieje bractwo Różańcowe.

Parafianie uczęszczają z pielgrzymkami do Tuchowa, Przeczycy i Czermina.

\section{JODEOWNIK (pow. Limanowa)}

Parafia istnieje od r. 1915. Kościół parafialny pod wezw. Narodzenia Maryi Panny zbudowany ok. 1585 r. ${ }^{67}$

W ołtarzu głównym pod tytulem Maryi znajduje się obraz Matki Boskiej $z$ Dzieciątkiem typu $M$. B. Śnieżnej malowany na płótnie w XVII w. Przy obrazie znajduje się 76 wotów. Z racji tego obrazu kościół posiadał w r. 1954 przywilej sanktuarium maryjnego. W ołtarzu umieszczony jest drugi obraz przedstawiający Ofiarowanie Maryi Panny malowany na płótnie w stylu klasycystycznym. W oltarzu bocznym obraz M. B. Nieustającej Pomocy.

Kościół polichromowany w w. XVIII ze scenami Zwiastowania i Koronacji Maryi Panny.

Na ścianie umieszczono nowy obraz Matki Boskiej.

Feretrony: 1) gipsowa figura Niepokalanie Poczętej; 2) gipsowa figura Matki Boskiej Różańcowej.

Choragwie i sztandary: 1) koloru czerwonego z obrazem malowanym w r. 1882 przedstawiającym Wniebowzięcie Maryi Panny, po drugiej stronie Wniebowstąpienie Pana Jezusa; 2) koloru białego z haftowanym obrazem M. B. Niepokalanie Poczętej, po drugiej stronie - św. Stanisława Kostki; 3) koloru czerwonego z XIX w. z malowanym obrazem M. B. Różańcowej, po drugiej stronie - Ukoronowania; 4) koloru czerwonego z XIX w. z malowanym obrazem M. B. Anielskiej, po drugiej stronie - Dzieciątka Jezus.

$\mathrm{Na}$ dwu białych ornatach widnieją haftowane przedstawienia Niepokalanego Poczęcia Maryi i M. B. Anielskiej.

W miejscowości Sadek, na placu gromadzkim stoi kaplica mszalna pod wezw. M. B. Częstochowskiej i z jej obrazem.

Kapliczki i figury: 1) w Jodłowniku, na polu plebańskim kapliczka z malowanym na płótnie obrazem Matki Boskiej. Miejscowa legenda głosi, że została wybudowana przez "jakiegoś pana", który, jadąc drogą prowadzącą $w$ dół, został poniesiony przez konie, lecz gdy wezwał pomocy Maryi, furmanka szczęśliwie się zatrzymała; 2) w Jodłowniku, na polu rodziny Taborów kapliczka z obrazem $M$. B. malowanym na płótnie; 3) w Górkach Jodłowskich, na realności rodziny Rusinów kapliczka

67 Dutki ewicz: Powiat limanowski s. 188 fig. 306; por. Z protokółów posiedzeń Grona. „Teka konserwat,” T. 1: 1900 s. 423. 
z malowanym obrazem Maryi; 4) w Kostnej, na polu rodziny Sliwów kapliczka z malowanym obrazem Matki Boskiej.

W Muzeum Diecezjalnym w Tarnowie znajduje się obraz w formie małego tryptyku $(131 \times 90,5 \mathrm{~cm}) \mathrm{z}$ pocz. XVI w. przedslawiający Zwiastowanie (nr inw. 127). Scena wyrażona na tle architektoniczno-krajobrazowym w otoczeniu św. Jana Chrzciciela i św. Dominika (z tego tytułu, że Jodłownik wówczas stanowił własność oo. dominikanów), u dołu zaś nieznany bliżej fundator z herbem Gryf. Obraz wykazuje wpływy niderlandzkie, niemniej odznacza się wielu cechami krakowskiej roboty ${ }^{68}$. Ponadto przechowuje się tutaj renesansowy oltarzyk tryptykowy z nastawą przedstawiający Wniebowzięcie Maryi Panny (nr inw. 126).

Przy kościele istnieje bractwo Różańcowe. Księga bracka istnieje od r. 1731.

Spiewa się dwie pieśni lokalne:

1) O Matko nasza, Jodłownicka Pani (4 zwrotki).

2) Do stóp Twych, nasza Pani (5 zwrotek).

Parafianie uczęszczają z pielgrzymkami do Kalwarii Zebrzydowskiej na dzień 15 sierpnia oraz do Częstochowy na uroczystość M. B. Różańcowej.

\section{JODŁOWKA TUCHOWSKA (pow. Tarnów)}

Parafia istnieje od r. 1840. Kościół parafialny pod wezw. św. Michała Archanioła zbudowany w r. 1871.

W ołtarzu bocznym poświęconym Maryi znajduje się obraz Matki Boskiej Różańcowej malowany na płótnie w końcu XIX w.

$\mathrm{Na}$ ścianie zawieszono oleodrukowy obraz M. B. Nieustającej Pomocy.

W witrażach znajdują się przedstawienia M. B. Różańcowej oraz Maryi z Dzieciątkiem Jezus i św. Janem.

Feretrony: 1) gipsowa figura Niepokalanej; 2) z malowanym na płótnie obrazem M. B. Szkaplerznej, po drugiej stronie - Serca Jezusa.

Chorągwie i sztandary: 1) koloru białego z malowanym obrazem M. B. Niepokalanie Poczętej, po drugiej stronie - św. Stanisława Kostki; 2) koloru białego z malowanym na płótnie obrazem przedstawiającym dziecięcą Maryję leżącą na kolanach św. Anny i czytającą książkę; 3) koloru czarnego z malowanym na płótnie obrazem M. B. Szkaplerznej wybawiającej dusze z czyśćca, po drugiej stronie - Chrystusa Zmartwychwstałego. kalanej.

Na białym ornacie przedstawiona jest haftowana podobizna Niepo-

68 Por. Z protokołów posiedzeń Grona. Tamże s, 423; Ks. Leśn i a k, jw: s. 22, 32 ; St. Zachorska: Dzieje malarstwa polskiego. W: „Wiedza o Polsce”. Warszawa $1932 \mathrm{~s} .115 ; \mathrm{K}, \mathrm{Gu} \mathrm{t}$ a nó w n a: Wpływy niderlandzkie na średniowieczne malarstwo cechowe w środowisku krakowskim. Kraków 1933 s, 15 fig. 13 , 
Kaplice mszalne: 1) pod wezw. Matki Boskiej z Góry Karmelu fundowana przez Pawła Rzepkę w r. 1892; w ołtarzu znajduje się obraz Matki Boskiej z Dzieciątkiem; 2) na realności Bronisława Wańtucha pod wezw. Matki Boskiej Śnieżnej z obrazem w ołtarzu M. B. Snieżnej zbudowana w 1913 r.; 3) zbudowana w r. 1931 przez Klemensa Dudka jako wotum za wyzdrowienie syna; w ołtarzu mieści się obraz M. B. Tuchowskiej.

Kapliczki i figury: 1) na realności Jana Wańtucha kamienna figura M. B. Różańcowej z r. 1914; 2) na gruncie Józefa Szarego kamienna figura M. B. Szkaplerznej; 3) kamienna figura M. B. z Lourdes z r. 1903; 4) na polu Julii Wańtuch kamienna figura M. B. Różańcowej fundowana w r. 1909 jako wotum dziękczynne; 5) kapliczka kamienna z XIX w. z dwoma oleodrukowymi obrazami M. B. Tuchowskiej; 6) kamienna figura M. B. z Dzieciątkiem.

Najczęściej i najliczniej parafianie uczęszczają na odpusty do Tuchowa w dniach od 2 do 9 lipca a poza tym w każdym roku (w Wielkim Tygodniu i na uroczystość Wniebowzięcia) z parafii udają się dwie pielgrzymki do Kalwarii Zebrzydowskiej.

\section{JURKÓW k/DOBREJ (pow. Limanowa)}

Parafia istnieje od $1913 \mathrm{r}$. Kościół parafialny pod wezw. M. B. Nieustającej Pomocy zbudowany w tymże roku.

W głównym ołtarzu znajduje się obraz M. B. Nieustającej Pomocy malowany na plótnie $w$ r. 1921. W bocznym oltarzu umieszczona jest kopia cudownego obrazu M. B. Bolesnej z kościoła franciszkańskiego w Krakowie. W kościele znajduje się mały oltarzyk maryjny z obrazem Matki Boskiej Częstochowskiej.

Feretrony: 1) figura N.M.P. Niepokalanie Poczętej; 2) figura Matki Boskiej Królowej z Dzieciątkiem; 3) malowany na blasze obraz M. B. Nieustającej Pomocy, po drugiej stronie -- M. B. Różańcowej.

Chorągwie i sztandary: 1) koloru czerwonego z malowanym na płótnie obrazem M. B. Ostrobramskiej, po drugiej stronie - $\dot{s} w$. Cecylii; 2) koloru zielonego z malowanym obrazem Wniebowzięcia Panny Maryi, po drugiej stronie - św. Antoniego; 3) koloru czarnego z malowanym na płótnie obrazem M. B. Tuchowskiej, po drugiej stronie - Pana Jezusa na krzyżu.

Kapliczki i figury: 1) w Jurkowie koło kościoła, na gruncie Jana Trzóbka grota kamienna z figurą M. B. Niepokalanie Poczętej; 2) w Jurkowie, w osiedlu "Kuligi" kapliczka z obrazem M. B. Kochawińskiej; 3) na granicy Jurkowa, na parceli rodziny Czyrnków kamienna figura Matki Boskiej; 4) w Jurkowie, "na Pulkówku” kamienna figura Niepokalanej; 5) w Jurkowie, „na Wróblówce" kapliczka z figurą Niepokalanej; 6) w Chyszówkach, w osiedlu Tracze gipsowa figura Matki Boskjej; 7) w Chyszówkach, "na Wilkach" gipsowa figura Matki Boskiej 
8) w Chyszówkach, w osiedlu Wyrwichy gipsowa figura Matki Boskiej; 9) w Chyszówkach, „na Moczarnikach“ gipsowa figura Matki Boskiej; 10) w Chyszówkach, na realności rodziny Jonów gipsowa figura Maiki Boskiej; 11) w Chyszówkach, na gruncie rodziny Zawadów gipsowa figura Matki Boskiej; 12) w Półrzeczkach, na polu rodziny Myszów figura Matki Boskiej; 13) w Półrzeczkach, na realności rodziny Jaroszów figura Matki Boskiej; 14) w Półrzeczkach, na własności rodziny Mrózków figura Matki Boskiej; 15) w Pólrzeczkach, na placu rodziny Homów figura Matki Boskiej; 16) w Wilczycach, na gruncie rodziny Pulków figura Matki Boskiej; 17) w Wilczycach na gruncie rodziny Dudzików figura Matki Boskiej; 18) w Wilczycach, na polu rodziny Janików figura Matki Boskiej; 20) w Wilczycach, na gruncie rodziny Miłków figura Matki Boskiej; 21) w Wilczycach, "na Łostóweczce" na polu rodziny Żaków figura Matki Boskiej; 22) w Wilczycach "na Łostóweczce", na realności rodziny Czyrnków figura Matki Boskiej; 23) w Wilczycach "na Łostóweczce", na tzw. "Zagrodach" figura Matki Boskiej.

Przy kościele istnieje Żywy Różaniec. Przy odsuwaniu obrazu M. B. Nieustającej Pomocy w wielkim ołtarzu śpiewa się pieśń:

Witaj Jurkowska Matko Jedyna,

uproś nam laskę u Twego Syna.

Witaj nam, witaj Niepokalana,

witaj nam, witaj Matko Kochana.

Parafianie zasadniczo uczęszczają z pielgrzymkami do Kalwarii Zebrzydowskiej na święta Matki Boskiej. Ponadto raz w roku udają się do Częstochowy, Lubomierza, Ludźmierza, Szczyrzyca i Dobrej.

\section{JURKOW k/TARNOWA (pow. Tarnów)}

Parafia istnieje od drugiej poł. XIII w. Kościół murowany pod wezw. Sw. Trójcy wybudowany w r. 1855.

W głównym ołtarzu znajduje się malowany na płótnie obraz Matki Boskiej z Dzieciątkiem. W ołtarzu bocznym pod tyt. Matki Boskiej znajduje się grota z figurą M. B. z Lourdes, pochodząca z ok. 1900 r, oraz z obrazem M. B. Nieustającej Pomocy z 1956 r. W drugim bocznym ołtarzu pod wezw. Sw. Trójcy mieści się malowany na płótnie obraz Zwiastowania.

Feretrony: 1) drewniana figura M. B. Niepokalanej z r. 1900; 2) drewniana figura Matki Boskiej z Dzieciątkiem; 3) drewniana płaskorzeźba z obrazem Serca Maryi, z drugiej strony - Serca Jezusowego; 4) drewniana płaskorzeźba z obrazem M. B. z Dzieciątkiem, po drugiej stronie - św. Teresy od Dzieciątka Jezus; 5) malowany na plótnie w $1871 \mathrm{r}$. obraz Maryi Uwielbionej, po drugiej stronie - św. Alojzego.

Chorągwie i sztandary: 1) koloru biało-czerwonego z malowanym na płótnie obrazem M. B. Częstochowskiej, po drugiej stronie - haftowanym św. Stanisława Kostki; 2) koloru biało-niebieskiego z malowanym na płótnie obrazem M. B. Niepokalanej, po drugiej stronie - Swię- 
tej Rodziny; 3) koloru biało-czerwonego z malowanym na płótnie obrazem Serca Maryi, po drugiej stronie - Serca Pana Jezusa; 4) koloru zielonego z malowanym na płótnie obrazem M. B. Różańcowej, po drugiej stronie - Swiętej Rodziny; 5) koloru białego z malowanym na plótnie obrazem M. B. Częstochowskiej, po drugiej stronie - św. Stanisława Bpa; 6) koloru białego z malowanym obrazem Serca Maryi i napisem: "Niepokalane Serce Maryi bądż naszym zbawieniem 1951", z drugiej strony - św. Sebastiana; 7) koloru biało-czerwonego z malowanym obrazem Wniebowzięcia, po drugiej stronie - Koronacji Maryi Panny; 8) koloru czarnego z malowanym obrazem M. B. Szkaplerznej na tle dusz czyśćcowych, po drugiej stronie -- Chrystusa Ukrzyżowanego.

W Ilkowicach znajduje się murowany kościół wybudowany w r. 1881 pod wezw. św. Sebastiana jako wotum za uchronienie od zarazy, z obrazem w ottarzu M. B. Niepokalanie Poczętej. W Łęgu Tarnowskim (Pogwizdów) murowana kaplica mszalna z figurą $M$. B. Różańcowej w oltarzu. W Niedomicach drewniana kaplica publiczna z $1957 \mathrm{r}$. z gipsową figurą Niepokalanej w ołtarzu. W przyszłości na tym miejscu ma stanąć kościół nowopowstającej parafii. W Niedomicach, koło szosy do Żabna kaplica z oltarzem i obrazem Maryi.

Kapliczki i figury: 1) w Ilkowicach przy szosie Tarnów-Żabno kamienna figura M. B. Łaskawej; 2) w Łęgu Tarnowskim, przy szosie Tarnów-Żabno kamienna figura M. B. Różańcowej; 3) w Łęgu Tarnowskim, obok przystanku kolejowego Niedomice kapliczka Matki Boskiej; 4) w Siedlcu, przy wiejskiej drodze kamienna figura Matki Boskiej.

Od r. 1870 istnieje w parafii bractwo Niepokalanego Poczęcia i Różańca Sw. ${ }^{69}$

Luđność uczęszcza z pielgrzymkami do Częstochowy, Kalwarii Zebrzydowskiej, Tuchowa a najczęściej do Odporyszowa.

\section{KAMIENICA (pow. Limanowa)}

Parafia istnieje od 1330 roku, dawniej jako własność konwentu PP. Klarysek w Starym Sączu. Kościół parafialny pod wezwaniem Przemienienia Pańskiego zbudowany w r. 1936. Drugi odpust obchodzony jest w dniu 2 lipca. Dawniej kościół nosił wezwanie Nawiedzenia Maryi Panny.

W ołtarzu głównym znajauje się obraz M. B. Częstochowskiej. W bocznym ołtarzu umieszczony jest malowany na płótnie obraz $\mathrm{M}$. B. Różańcowej, początkowo pozostający w ołtarzu głównym. W nowopowstałym ołtarzu umieszczono gipsową figurę Niepokalanej. W bocznym ołtarzu Serca Jezusowego znajduje się oleodrukowy obraz Serca Maryi. W kruchcie w ołtarzu bł. Kingi jest malowany na desce obraz M. B. Częstochowskiej. W prezbiterium na ścianie zawieszono malowany na płótnie obraz M. B. Częstochowskiej. 
Feretrony: 1) drewniana figura Niepokalanej z 1931 r.; 2) drewniana figura Serca Maryi; przy figurze wota złożone za otrzymane łaski; 3) ma-lowany na płótnie obraz św. Anny z Matką Boską, po drugiej stronie św. Teresy.

Sztandary i chorągwie: 1) koloru niebiesko-białego z malowanym obrazem przedstawiającym Zwiastowanie, po drugiej stronie Chrystusa Króla; 2) koloru biało-czerwonego $\mathrm{z}$ malowanym na płótnie obrazem M. B. Częstochowskiej, po drugiej stronie Serca Jezusa; 3) koloru białoczerwonego z malowanym na plótnie obrazem Serca Maryi, po drugiej stronie Serca Pana Jezusa; 4) koloru białego z malowanym na plótnie obrazem M. B. Różańcowej, po drugiej stronie św. Franciszka z Asyżu; 5) koloru czarnego z malowanyin na płótnie obrazem M. B. Bolesnej, po drugiej stronie Chrystusa w Ogrójcu.

Na białym ornacie wyhaftowano w r. 1951 postać M. B. Częstochowskiej. Na puszce z $1925 \mathrm{r}$. widnieje wizerunek M. B. Bolesnej a na kielichu Madonny z Dzieciątkiem.

W Muzeum Diecezjalnym w Tarnowie znajduje się ormat (nr inw. 386) z kolumną haftowaną, umieszczoną na weneckim aksamicie z w. XIX, zastępującym dawną tkaninę adamaszkową, która juź w r. 1608 była spłowiała ${ }^{70}$. Kolumna $\mathrm{z}$ końca XV w. przedstawia haftowaną scenę Chrystusa wiszącego na krzyżu w otoczeniu czterech Ewangelistów oraz M. B. Bolesnej i św. Jana u dołu krzyża ${ }^{i 1}$.

Kaplice mszalne: 1) w Kamienicy Dolnej, na posiadłości Wawrzyńca i Michała Mikołajczyków kaplica kamienna postawiona prawdopodobnie w r. 1847 jako wotum za ocalenie w czasie grasującej zarazy. Wewnątrz ołtarzyk z płaskorzeźbionym obrazem Maryi Niepokalanie Poczętej, na ścianie obraz M. B. Kalwaryjskiej i Droga Krzyżowa; 2) w Szczawie na posiadłości Franciszka Wiatra murowana w kamieniu kaplica z XVIJI w., ozdobiona wieżyczką, pokrytą niegdyś gonlem, obecnie blachą. W ottarzu znajduje się obraz M. B. Częstochowskiej prawdopdobnie z pocz. XIX w. czczony specjalnym kultem. W ubiegłym wieku, kiedy w okolicznych wsiach umierało dziennie po kilkanaście osób na cholere, miejscowa ludność gromadziła sie na modlitwee przed tym obrazem. Według. opowiadań starszych osób nikt z miejscowej wsi nie zachorował na tę chorobę; 3$)$ w Szczawie, przy szosie na realności Franciszka Chlipary znajduje się inna kaplica murowana w kamieniu pochodząca z XIX w. Wewnątrz nad wejściem wisi malowany na ścianie obraz Madonny z Dzieciątkiem. W ołtarzu znajduje się obraz Niepokalanego Poczęcia czczony równieź przez miejscową ludność jako skuteczny w zanoszonych prośbach; 4) w Zalesiu kaplica będąca własnością gospodarzy Kominów, pozostająca pod opieką Michała Wierzyckiego, fundowana przez

70 Wizytacja dek. bobowskiego z 1608 r. k. 52 (Arch. Kap. Metrop. Krak.).

71 "Teka konserwat." T. 1: $1900 \mathrm{s.} 422$; L. Le psz y: Muzeum w Tarnowie. „Teka konserwat." T. 2: 1906 s. 355 fig. 17; $\mathrm{z}$. Wi n i a rzó w na: Gotyckie hafty z Ukrzyżowaniem w Muzeum Diec. w Tarnowie. Rps. s. 9-10, 28-29 przyp. 14, tabl. 8 . 
Szymona Biańka na początku XIX w., powiększona w r. 1896, z dwoma ołtarzykami typu ludowego ${ }^{72}$ i obrazem M. B. Częstochowskiej. Obok na ołtarzu znajduje się figura Chrystusa przy słupie. Legenda głosi, że pewien złodziej chciał ją ukraśc, lecz gdy ją wziął w ramiona, tak mu zaciążyła, iź nie mógł zrobić ani kroku i musiał zostawić ją na miejscu. Po drugiej stronie znajduje się drewniana figura Niepokalanej. Kaplica jest licznie uczęszczana przez miejscową ludność ${ }_{i}$ 5) również w Zalesiu murowana kaplica $\mathrm{w}$ środku wioski, w-osiedlu rodziny Franczyków z pierwszej poł. XIX w., malowana w r. 1842 przez Józefa Gubalskiego (sygnatura na ścianie), posiadająca w ołtarzu obraz M. B. Częstochowskiej. Na ścianie znajduje się drugi, starszy obraz M. B. Częstochowskiej malowany na plótnie, uznawany przez miejscową ludność jako łaskami słynący; 6) w Zalesiu, na realności rodziny Sopatów stoi murowana kaplica fundowana ok. $1850 \mathrm{r}$, przez Jana Sopate z ołtarzem i płaskorzeźbionym obrazem Matki Boskiej czczonym jako M. B. Pocieszenia; 7) $w$ Zbludzy jest murowana $w$ kamieniu kaplica $z$ sygnaturką, fundowana w pierwszej pol. XIX w. ${ }^{73}$, według podania jako wotum w czasie panującej zarazy, z obrazem M. B. Częstochowskiej w ołtarzu. Po lewej stronie oltarza znajauje się malowany na papierze obraz $M$. B. Leżajskiej a nad nim koronacja Maryi. Obok znajduje się malowany na płótnie obraz M. B. Dobrej Rady a po prawej stronie ołtarza M. B. Różańcowej.

Kapliczki i figury: 1) na cmentarzu murowana kaplica grobowa rỏdziny Szalayów z pocz. XIX w. z obrazem Ofiarowania Maryi Panny, pochodzącym $z$ tego samego czasu $_{i}$ 2) w Kamienicy kamienna kapliczka z rzeźbą Chrystusa w Ogrojcu, poniżej ze szklanym obrazem Malki Boskiej; 3) w Zbludzy w polu kamienna kapliczka na słupie $z$ figurą Matki Boskiej z ok. poł. XIX ${ }^{*} w{ }^{7}{ }^{7}$; 4 ) w Zbludzy murowana kapliczka $\mathrm{z}$ ołtarzykiem skonstruowanym $\mathrm{w}$ charakterze ludowego baroku ${ }^{75} \mathrm{i}$ płaskorzeżbą $w$ drzewie M. B. Częstochowskiej oraz $\mathrm{z}$ obrazem na ścianie równieź M. B. Częstochowskiej.

Przy kościele jest bractwo Żywego Róźańca. Wierni uczęszczają z pielgrzymkami do Kalwarii Zebrzydowskiej oraz do Czarnego Potoku.

\section{KAMIONKA MAŁA (pow, Limanowa)}

Parafia istnieje od drugiej poł. XIV w. z przerwą w latach 1526-1925 kiedy to należała do parafii Ujanowice. Obecny kościół drewniany pod wezw. św. Katarzyny wybudowany został prawdopodobnie w XVII w.

W głównym ołtarzu pod wezwaniem św. Katarzyny znajduje się drewniana figura Niepokalanej z ok. $1900 \mathrm{r}$. W bocznym ołtarzu pod wezwaniem Matki Boskiej znajduje się drewniana figura M. B. Różań-

zz D u tk i e wi c z: Powiat limanowski s. 208.

73 Tamże.

74 Tamże.

75 Tamże. 
cowej z ok. 1900 roku, zasuwana obrazem św. Benona. W drugim bocznym ołtarzu pod wezwaniem św. Józefa, w górnej części ołtarza znajduje się malowany na płótnie obraz M. B. Bolesnej z ok. 1870 roku.

Polichromia, autorstwa Miklasińskiego z Bochni z r. 1888, przedstawia na stropie obraz Matki Boskiej z napisem "Regina Angelorum ora pro nobis".

Obrazy na ścianach: 1) w kruchcie znajduje się malowany na płótnie obraz M. B. Kodeńskiej; 2) w przedsionku malowany na plótnie obraz Madonny z Dzieciątkiem z 1795 r.; 3) na ścianie nowy obraz M. B. z Dzieciątkiem z XVII w.; 4) w skarbcu płaskorzeźbiony obraz M.B. Częstochowskiej z XVIII w.

Feretrony: 1) drewniana rzeźba Niepokalanej z ok. 1900 r.; 2) drewniana rzeźba z ok. $1900 \mathrm{r}$; 3) oleodrukowy obraz z ok. 1870 r. M. B. Róźańcowej, po drugiej stronie św. Antoniego.

Chorągwie i sztandary: 1) koloru czerwonego z malowanym obrazem M. B. Bolesnej, po drugiej stronie św. Józefa, pochodząca z 1939 r.; 2) koloru czerwonego z malowanym obrazem Nieustającej Pomocy, po drugiej stronie św. Katarzyny, pochodząca również z 1939 r.

W Muzeum Diecezjalnym w Tarnowie znajduje się tryptyk szkoły sądeckiej z ok, 1420 r. (nr inw. 148) przeniesiony tutaj z klasztoru PP. Klarysek ze Starego Sącza ${ }^{76}$. Brak środkowej figury, którą była zapewne Madonna z Dzieciątkiem. Na awersach skrzydeł postacie świętych Anny Samotrzeciej, Zofii z trzema Córkami, Doroty, Katarzyny, na rewersach Chrystusa Boleściwego i Maryi Bolesnej z mieczem boleści. Obiekt ten stanowi czołową pozycję pierwszej epoki malarstwa gotyckiego w Polsce, powiązanego $z$ inspiracyjnymi źródłami proterenansowymi przejętymi w Polsce za pośrednictwem Czech ${ }^{7}$.

Kapliczki i figury: 1) na reainości rodziny Grzegorzków - Chełmeckich z malowaným na szkle ludowym obrazkiein $M$. B. Częstochowskiej. Tradycja mówi, że dziadek obecnego właściciela Jan Grzegorzek, ojciec siedmiorga zmarłych dzieci, odbyl pieszo pielgrzymkę do Częstochowy i jako wotum błagające przyniósł stantąd obraz Matki Boskiej, który umieścił w kapliczce. Odtąd przestały mu umierać dzieci i troje z nich zostało przy życiu; na parceli rodziny Groniów figura Niepokalanego Poczęcia rzeżbiona w r. 1958 przez miejscowego rzeźbiarza Jana Stacha; 3) na realności rodziny Koconiów kapliczka uwieńczona krzyżem powstała w r. 1870, z figurą drewnianą Matki Boskiej.

Parafianie uczęszczają z pielgrzymkami do Kalwarii Zebrzydowskiej na Wielki Piątek i dni poprzedzające uroczystość Wniebowzięcia a czasem do Tuchowa.

76 „Teka konserwat." T. 1: 1900 s. 422.

77 M. W alicki: Ze studiów nad malarstwem cechowem ziemi sadeckiej w XV w. W: „Prace KHS PAU”. T. 6: 1935 z. 2 s. 11-12; te n że: Polska sztuka gotycka s. $15 \mathrm{fig}, 6$; t e nz e: Malarstwo polskie XV w. s. $67-69$ ryc. $6-7,50$. 


\section{KAMION.KA WIELKA (pow. Nowy Sącz)}

Parafia istnieje od drugiej pol. XIV w. Kościół parafialny murowany pod wezwaniem św. Bartłomieja wybudowany w latach 1621-30.

W ołtarzu głównym pod wezwaniem św. Barłłomieja umieszczono na szczycie drewnianą figurę M. B. z Dzieciątkiem z XIX w. i obraz M. B. Nieustającej Pomocy.

W ołtarzu kaplicy znajduje się malowany na blasze miedzianej ok. 1880 r. obraz Madonny z Dzieciątkiem ${ }^{i 8}$. Z racji tego obrazu kościól posiadal w r. 1954 przywilej sanktuarium maryjnego.

Obrazy w kościele: 1) na ścianie zawieszono malowany na blasze obraz M. B. Bocheńskiej; 2) malowany obraz Świętej Rodziny z XVIII w.; 3) na wieży kościelnej malowany na desce obraz M. Boskiej; 4) drewniana rzeźba z M. B. Bolesną i św. Janem; 5) kamienna figura M. B. w oknie wieży.

Feretrony: 1) malowany na blasze obraz M. B. Szkaplerznej, po drugiej stronie św. Józefa; 2) malowany na desce obraz M. B. Tuchowskiej, po drugiej stronie Przemienienia Pańskiego; 3) gipsowa figura Maryi Niepokalanej.

Chorągwie i sztandary: 1) koloru czerwonego z malowanym obrazem M. B. Szkaplerznej, po drugiej stronie Serca Pana Jezusa, fundacji Emilii Korczyńskiej z 1900 r.; 2) koloru czerwonego z malowanym obrazem M. B. Niepokalanej, po drugiej stronie św. Stanisława; 3) koloru niebieskiego z malowanym obrazem Serca Maryi, po drugiej stronie Pana Jezusa; 4) koloru zielonego z malowanym obrazem Maryi Niepokalauej, po drugiej stronie św. Józefa; 5) koloru białego z malowanym obrazem M. B. Częstochowskiej, po drugiej stronie Serca Pana Jezusa.

Kapliczki i figury w Kamionce Wielkiej: 1) na drzewie koło domu Stanisława Poręby z drewnianą figurą Niepokalanej; 2) koło domu Jana Ogórka na postumencie kamiennym szafka z figurą Maryi Niepokalanej; 3) "na roli Kosówka" na żelaznej podstawie blaszana szafka z figurą Matki Boskiej, fundowana przez Józefa Kościółka; 4) koło domu Anàrzeja Kaczmarka stoi murowana kapliczka z figurami wewnątrz Pana Jezusa na krzyżu, Matki Boskiej i św. Jana; 5) koło drogi "na Surmówce" figura M. B. Bolesnej z roku 1846; 6) "na Balcerówce" kapliczka z ołtarzykiem wewnątrz i obrazem malowanym na desce M. B. Częstochowskiej oraz rzeżbami ludowymi; 7) na realności rodziny Frączkóiw murowana kaplica $z$ ołtarzykiem i malowanym na płótnie obrazem M. B. Kalwaryjskiej. Na ścianie po prawej stronie obraz M. B. Bolesnej z mieczem boleści, na lewej ścianie figura Matki Boskiej z Dzieciątkiem i napisem u dołu „A. D. 1887. 23. III."; 8) w górzystej części wsi „pod Margoniem" kapliczka z gipsową figurą Matki Boskiej fundowana przez Dymitra Tudonia; 9) na pograniczu Kamionki i Nawojowej cirewniana figura Maryi pod krzyżem.

78 Kronika parafii Kamionka W. (na miejscu). 
Przy kościele istnieje Żywy Róźaniec. Parafianie uczęszczają z pielgrzymkami na 15 sierpnia i Wielki Piątek do Kalwarii Zebrzydowskiej a ponadto do Częstochowy, Nowego Sącza (OO. Jèzuici) i Tuchowa.

\section{KAMIONNA (pow. Bochnia)}

Parafia istnieje od roku 1934. Kościół parafialny pod wezwaniem Królowej Korony Polskiej zbudowano w 1934 r.

W głównym ołtarzu znajduje się malowany na płótnie obraz M. B. Częstochowskiej. W bocznym oltarzu maryjnym znajduje się figura M. B. Niepokalanie Poczętej.

$\mathrm{Na}$ ścianie zawieszony jest oleodrukowy obraz M. B. Nieustającej Pomocy.

Feretrony: 1) gipsowa figura Matki Boskiej Niepokalanie Poczętej 2) malowany na płótnie obraz M. B. Bolesnej, po drugiej stronie Pana Jezusa z napisem "Jezu ufam Tobie".

$\mathrm{Na}$ bialym ornacie umieszczono haftowany obraz M. B. Czestochowskiej.

Kapliczki i figury przydrożne w Kamionnej: 1) kamienna figura M. B. Różańcowej z 1857 r.; 2) kapliczka z obrazem Maryi w białej sukni, nazywanej tutaj „Matką Boską Pasterską"; 3) kapliczka z oleodrukowym obrazem M. B. Częstochowskiej; 4) kapliczka z oleodrukowym obrazem M. B. Częstochowskiej; 5) kapliczka z oleodrukowym obrazem M. B. Nieustającej Pomocy.

Przy kościele istnieje Bractwo Różańcowe. Parafianie najchętniej uczęszczają na odpusty do Kalwarii Zebrzydowskiej, poza tym do Czšslochowy, Pasierbca i Limanowej.

\section{KANINA (pow. Limanowa)}

Parafia istnieje od drugiej poł. XV w. Kościół parafialny murowany pod wezwaniem św. Marii Magdaleny zbudowany na miejscu starego, spalonego w r. 1894.

W głównym ołtarzu pod wezwaniem Swiętej Trójcy jest malowany na płótnie obraz M. B. Pocieszenia. W ołtarzu bocznym pod wezwaniem Marii Magdaleny znajduje się malowany na płótnie obraz Marii Magdaleny, zmieniany często na obraz M. B. Róźańcowej. W oftarzu pod wezwaniem św. Józefa pod głównym obrazem wisi oleodrukowy obraz M. B. Nieustającej Pomocy. W bocznym ołtarzu pod wezwaniem Serca Pana Jezusa znajduje się oleodrukowy obraz M. B. Siedmiu Boleści.

Feretrony: 1) drewniana figura Niepokalanej; 2) drewniana figura M. B. z Dzieciątkiem; 3) drewniana figura Serca Maryi; 4) malowany na desce obraz M. B. z Dzieciątkiem, po drugiej stronie św. Franciszka i św. Dominika. 
Chorągwie i sztandary: 1) koloru czerwonego .z malowanym obrazem M. B. Różańcowej, po drugiej stronie św. Michała Archanioła; 2) koloru czerwonego z malowanym obrazem Maryi Niepokalanej, po drugiej stronie św. Marii Magdaleny; 3) koloru czerwonego z malowanym obrazem M. B. Szkaplerznej, po drugiej stronie św. Antoniego; 4) koloru czerwonego z malowanym obrazem M. B. Częstochowskiej, po drugiej stronie św. Stanisława ze Szczepanowa; 5) koloru zielonego z malowanym obrazem Swiętej Rodziny, po drugiej stronie św. Jana Kantego błogosławiącego chorą niewiastę.

Kaplice i figury: 1) w Kaninie, na polu plebańskim "na Buczkach" kaplica Serca Maryi z oleodrukowym obrazem tego tytułu; 2) w Kaninie, na polu Karoliny Lis kapliczka na słupie z drewnianą figurą Piety, odnowiona w 1884 r.; 3) w Siekierczynie, na polu Zygmunta Wiktorka murowana kapliczka z gipsową figurą Niepokalanej, postawiona po ostatniej wojnie jako wotum za szczęśliwą ucieczkę z rąk Gestapo ojca właściciela; 4) W Siekierczynie "na Podstawach", na realności Franciszka Górki murowana kapliczka z rzeźbą M. B. Różańcowej, postawiona w r. 1948 na miejscu starego krzyża jako wotum za ocalenie syna właściciela z rąk Niemców; 5) w Siekierczynie, na polu Józefa Ciuły kapliczka na słupie z drewnianą figurą M. B. z Lourdes; 6) w Siekierczynie, na polu Walentego Mruka drewniana rzeźba Piety Limanowskiej umieszczona na słupie; 7) w Siekierczynie, na domu Jana Opieli malowany na płótnie obraz Maryi Niepokalanego Poczęcia z XIX w.; 8) w Siekierczynie, na polu Michała Lisa, na miejscu dawnego krzyża umieszczona została figura Maryi Niepokalanej; 9) w Siekierczynie, na polu Antoniego Młynarczyka, na dawnym cmentarzu cholerycznym krzyż z figurą Niepokalanego Poczęcia; 10) w Siekierczynie, na polu Stanisława Pałki, na miejscu dawnego krzyża umieszczona ostatnio figura M. B. z Lourdes; 11) w Siekierczynie, na polu Barbary Król kamienna rzeżba Limanowskiej Piety i obraz Nieustającej Pomocy z 1905 r.; 12) w Siekierczynie, na polu Józefa Wiśniowskiego, na miejscu starego krzyża umieszczono ostatnio kapliczkę z gipsową figurą Niepokalanej; 13) w Wysokim, na realności Andrzeja Jaworskiego murowana kaplica z XVIII w. posiada kamienną rzeźbę Swiętej Rodziny; 14) w Wysokim, na realności Józefa Kamińskiego kaplica z malowanym obrazem M. B. Częstochowskiej z XIX w. postawiona na miejscu zniszczonej podczas ostatniej wojny światowej; 15) w Wysokim "na Karczówce", przy domu rodziny Kotlarzów murowana kaplica pod wezwaniem Niepokalanego Poczęcia z pocz. XIX w. z drewnianą rzeźbą Niepokalanej z tego samego czasu; 16) W Wysokim, na polu Franciszka Kubackiego murowana kaplica z 1917 roku z rzeźbą Chrystusa Ukrzyżowanego i Maryi wewnątrz; 17) w Woli Brzezińskiej, na realności Jakuba Kubackiego kapliczka na słupie z figurą M. B. Różańcowej i Serca Maryi.

Parafianie uczęszczają na odpusty do Kalwarii Zebrzydowskiej, a poza tỵm do Limanowej, Czarnego Potoku, Szczygańca (par. Podegro- 
dzie) i czasem do Tuchowa. W parafii istnieje zwyczaj święcenia bukietów tzw. „ziela" składającego się z liczniczych ziól, kwiatów, owoców i kłosów zboża. Ziele umieszcza się potem w domu lub kapliczkach a ziarno z kłosów miesza się ze zbożem przenaczonym do siewu.

\section{KĄCLOWA (pow. Nowy Sącz)}

Parafia istnieje od r. 1929. Kościól drewniany pod wezwaniem św. Wojciecha zbudowany w r. 1929.

W ołtarzu bocznym pod wezwaniem Matki Boskiej znajduje się malowany na desce obraz M. B. Nieustającej Pomocy.

Na ścianie prezbiterium wiszą malowane na płótnie obrazy M. B. Różańcowej i Wniebowzięcia Maryi Panny.

Feretrony: 1) z malowanym na desce obrazem M. B. Bolesnej, po drugiej stronie Chrystusa w cierniowej koronie; 2) gipsowa figura Niepokalanej.

Sztandary i chorągwie: 1) koloru białego z malowanym obrazem Wniebowzięcia, po drugiej stronie św. Franciszka; 2) koloru białego z malowanym obrazem Niepokalanej, po drugiej stronie św. Tèresy od Dzieciątka Jezus; 3) koloru zielonego z malowanym obrazem M. B. Częstochowskiej, po drugiej stronie św. Stanisława Kostki; 4) koloru czarnego z malowanym obrazem Maryi pod krzyżem, po drugiej stronie Piety.

Kapliczki i figury: 1) w Kąclowej, na realności Kazimierza Skraby murowana kapliczka z 1848 r. posiada wewnątrz kilka obrazków oleodrukowych Matki Boskiej; 2) w Kąclowej, na polu Stanisława Romanka drewniana kapliczka z figurą Maryi; 3) w Kąclowej, na polu Eugeniusza Grucy figura Niepokalanej.

Parafianie uczęszczają z pielgrzymkami na odpusty do Kalwarii Zebrzydowskiej, Tuchowa, Dębowca i Biecza.

106. KLIKOWA (pow. Tarnów)

Parafia istnieje od roku 1947. Kościół murowany pod wezwaniem Serca Maryi wybudowano w 1949 r.

W ołtarzu wielkim znajduje się malowany na desce obraz M. B. Nieustającej Pomocy z ostatnich lat. W bocznym ołtarzu M. B. Bolesnej jest malowany na płótnie w XVII w. obraz Maryi pod krzyżem. W oltarzu kaplicy znajduje się gipsowa rzeźba M. B. Niepokalanej.

Chorągwie i sztandary: 1) koloru białego z malowanym i haftowanym obrazem M. B. Częstochowskiej, po drugiej stronie Orła Białego; 2) koloru biało-czerwonego z haftowanym Sercem Niepokalanej, po drugiej stronie św. Józefa rzemieślnika.

W Muzeum Diecezjalnym w Tarnowie znajduje się płaskorzeźbiona pasyjka z Matką Boską Bolesną pochodzącą z przydrożnej kapliczki z terenu tutejszej parafii (nr inw. 276).

W parafii istnieje bractwo Różańca Świętego. Wierni uczęszczają z pielgrzymkami do Tuchowa i Odporyszowa. 


\section{KOBYLANKA, (pow. Gorlice)}

Parafia istnieje od drugiej poł. XIV w. Kościół murowany pod wezwaniem św. Jana Chrzciciela zbudowany w r. 1650.

W ołtarzu głównym znajduje się słynny obraz cudowny Chrystusa na Krzyżu pochodzący $\mathrm{z}$ XVII $\mathrm{w}$. W bocznym ołtarzu wisi malowany na płótnie obraz M. B. Niepokalanie Poczętej z XVII w. W kaplicy znajduje się ołtarz z obrazem M. B. Saletyńskiej, namalowany staraniem XX. Saletynów sprawujących opiekę duszpasterską parafii.

Feretrony: 1) malowany obraz Madonny $z$ Dzieciątkiem; 2) figura Maryi Królowej Polskiej; 3) gipsowa figura Niepokalanej; 4) gipsowa figura Maryi z Dzieciątkiem.

Chorągwie i sztandary: 1) koloru żółtego z obrazem M. B. Saletyńskiej; 2) koloru białego z obrazem Maryi Królowej.

Na białym ornacie znajduje sie postać Matki Boskiej. Istniała tuiaj niegdyś wartościowa monstrancja rokokowa z medalionami z życia Chrystusa m. inn. Znalezienia Chrystusa w świątyni ${ }^{79}$.

Kapliczki i figury: 1) w Kobylance, na realności Franciszka Osikowicza kapliczka z przedstawieniem Maryi pod Krzyżem i obrazem Swiętej Rodziny na ścianie; 2) w Kobylance, na realności rodziny Sieradzkich kaplica z figurą M. Boskiej; 3) w Kobylance kaplica pod wezwaniem Serca Jezusowego z obrazem Swiętej Rodziny; 4) w Kobylance, na dębie w lesie "Rozbój” figurka Matki Boskiej; 5) w Kobylance ,koło Dworu" fundowana przez Skrzyńskich właścicieli majątku kapliczka z obrazem M. B. Częstochowskiej; 6) w Kobylance, na parceli rodziny Chardabusów kapliczka Pana Jezusa z obrazem Sw. Rodziny; 7) na granicy Kobylanki i Krygu kapliczka M. B. Różańcowej; 8) w Kobylance, na parceli rodziny Stępniów kapliczka M. B. Różańcowej; 9) w KobyJance, na parceli rodziny Gąsiorków kapliczka M. B. Różańcowej; 10) w Kobylance, na parceli rodziny Gogolów kapliczka M. B. z Dzieciątkiem; 11) w Dominikowicach, na realności Wojciecha Stępnia i jego fundacji murowana kaplica z gipsową figurą M. B. Różańcowej; 12) w Dowinikowicach, na realności Ludwika Kurka murowana kapliczka z gipsową figurą M. B. Różańcowej, wybudowana w r. 1952 jako wotum za odzyskane zdrowie; 13) w Dominikowicach, na parceli rodziny Ludwinów kamienna kolumna z figurą M. B. Różańcowej; 14) w Dominikowicach, na parceli Tadeusza Pietruszy kapliczká z obrazem Swiętej Rodziny wybudowana przez rodziców właściciela Franciszka i Krystynę jako wotum za wyzdrowienie Franciszka. Już obecnie powstała tradycja, że w czasie choroby męża Krystyna udała się do "jasnowidza", który z jakiejś księgi miał wyczyłać winy całej rodziny i nakazał aby ceiem przebłagania Boga wybudowano kaplice poświęconą Swiętej Rodzinie; 15) w Dominikowicach, na realności Wojciecha Sikory kapliczka z XIX w. z ludową rzeźbą Chrystusa i M. B. Bolesnej; 16) w Do-

79 Tom k owic z: Powiat gorlicki s. 256-257 ỉg. 54. 
minikowicach, na parceli rodziny Rybczyków fígura M. B. z Dzieciątkiem; 17) w Dominikowicach, na realności i z fundacji Błażeja Dutka krzyż z obrazem Swiętej Rodziny; 18) w Dominikowicach, na parceli rodziny Wańtuchów kamienna figura Matki Boskiej fundowana na podziękowanie za odkrycie na tej realności źródła nafty.

Przy kościele istnieje bractwo Różańca Świętego. Parafianie mało uczęszczają z pielgrzymkami do innych miejsc, mając u siebie wizerunek Chrystusa Ukrzyżowanego z XVII w. posiadającego szeroką sławę cudowności.

\section{KOLBUSZOWA}

Parafia istnieje od drugiej poł. XV w. Kościół parafialny murowany pod wezwaniem Wszystkich Swiętych zbudowany w r. 1936.

W ołtarzu głównym pod wezwaniem Maryi Panny znajduje się malowany na płótnie obraz Niepokalanego Poczęcia. W bocznym ołtarzu maryjnym znajduje się plaskorzeżbiony obraz M. B. Częstochowskiej, ofiarowany do kościoła podczas ubiegłej wojny. Przy obrazie znajduja się wota. W bocznym ołtarzu pod wezwaniem Sw. Józefa znajduje się oleodrukowy obraz M. B. Nieustającej Pomocy również z wotami.

Obok wejścia do bocznej nawy stoi oltarzyk z obrazem M. Boskiej.

Na ścianach kościoła wiszą: 1) malowany na płótnie z r. 1930 obraz M. B. Bolesnej; 2) oleodrukowy obraz M. B. Królowej Pokoju.

Polichromia kościoła wykonana w latach 1955-1957, poświecona w głównej mierze Matce Boskiej, posiada sceny Zwiastowania, Narodzenia, Ofiarowania, Znalezienia w świątyni, godów w Kanie Galilejskiej.

Jeden z witraży przedstawia podobiznę M. B. Częstochowskiej.

Feretrony: 1) z malowanym na blasze obrazem $M$. B. Bolesnej, po drugiej stronie Korony Cierniowej; 2) z malowanym na blasze obrazem Madonny Apokaliptycznej, po drugiej stronie św. Józefa; 3) z malowanym na płótnie obrazem M. B. Częstochowskiej, po drugiej stronie objawienia się Chrystusa św. Maryi Małgorzacie; 4) z malowanym na desce obrazem M. B. Częstochowskiej, po drugiej stronie M. B. Nieustającej Pomocy; (feretron ten noszą dziewczęta ubrane w krakowskie stroje); 5) z drewnianą figurą M. B. Różańcowej.

Chorągwie i sztandary: 1) koloru czerwonego z malowanym obrazem M. B. Częstochowskiej, po drugiej stronie św. Józefa; 2) koloru zielonego z malowanym obrazem Serca Maryi, po drugiej stronie Serca Pana Jezusa; 3) koloru czarnego z malowanym obrazem M. B. Bolesnej, po drugiej stronie Krzyża św.

Na cmentarzu znajduje się duża kaplica mszalna z ołtarzem i obrazem Maryi Wniebowziętej. W kostnicy na cmentarzu znajduje się barokowa rzeźbiona grupa Ukrzyżowania z Maryą i św. Janem. W Weryni koło stadionu, w dawnej kaplicy mszalnej dworskiej, znajduje się obraz M. B. Częstochowskiej. 
Kapliczki i figury: 1) w Kolbuszowej, przy ul. Narutowicza w murowanej kapliczce znajduje się przeniesiona z kościoła parafialnego ${ }^{80}$ rzeźbiona figura Anny Samotrzeć z ok. 1410 r. ${ }^{81}$; 2) w Kolbuszowej przy ul. 1-go Maja, koło domu Anny Serwańskiej na drzewie kapliczka M. B. Częstochowskiej; 3) w Kolbuszowej przy ul. 1-Maja, koło domu Jana Mierzejewskiego na drzewie kapliczka M. B. Częstochowskiej; 4) w Kolbuszowej, koło szkoły podstawowej kapliczka z obrazami M. B. Nieustającej Pomocy i M. B. Częstochowskiej; 5) w Kolbuszowej przy ul. 1-Maja wmurowany $w$ dom (obecnie poczta) oleodrukowy obraz M. B. Częstochowskiej; 6) w Kolbuszowej Dolnej, na realności Stanisława Karkuta olecdrukowy obraz M.B. Częstochowskiej; 7) w Kolbuszowej Górnej, na realności Jana Chmielowca w kapliczce na drzewie obraz M. B. Częstochowskiej; 8) w Kolbuszowej Górnej, na realności Michała Skowronskiego murowana kapliczka z krzyżem i figurą Matki Boskiej; 9) w Nowej Wsi, na realności Antoniego Steca w kapliczce na drzewie obraz M. B. Częstochowskiej; 10) w Nowej Wsi, na realności Michała Kiwaka w kapliczce na drzewie obraz M. B. Częstochowskiej; 11) w Nowej Wsi, na realności Jana Tokarza $w$ kapliczce na drzewie również obraz M. B. Częstochowskiej; 12) w Swierczowie, na realności Stefana Matejka krzyż z oleodrukowym obrazem M. B. Częstochowskiej; 13) w Weryni, koło szkoły murowana kolumna z obrazami M. B. Częstochowskiej i Nieustającej Pomocy; 14) w Weryni, po prawej stronie szosy od Kolbuszowej kapliczka z obrazem M. B. Częstochowskiej.

$\mathrm{Na}$ terenie parafii znajduje się jeszcze ok. 25 kapliczek i krzyżów przydrożnych poświęconych innym tematom.

W parafii istnieje bractwo Różańca i Szkaplerza Swiętego. Parafianie pielgrzymują do Leżajska i Borku ze względu na odbywającą się tam uroczystość Pogrzebu Matki Boskiej. Do Częstochowy jeżdżą tylko poszczególne osoby.

\section{KORZENNA (pow. Nowy Sącz)}

Parafia istnieje od pierwszej poł. XIV w. Kościól parafialny drewniany pod wezwaniem św. Urszuli i Towarzyszek ${ }^{8 z}$ spalił się w r. 1952. Nowy kościół w budowie. Nabożeństwa odbywają się w przebudowanej sali domu parafialnego.

Spalony kościół i jego wystrój wewnętrzny posiadał wysoką wartość artystyczną i zabytkową ${ }^{83}$. Tylko kilka mniejszej wartości obiektów zdołano wyratować z wnętrza podczas pożaru.

W tymczasowej kaplicy w wielkim ołtarzu znajduje się obraz malowany w r. 1953 przez ks. A. Stachonia z Nowego Sącza, kopia czczo-

80 Wizytacja dek. rudnickiego i miechocińskiego z r. 1748 k. 56 (w Archiw. Kap. Krak.).

$81 \mathrm{D} \mathrm{utkiewicz:}$ Małopolska rzeźba średniow. s, 145 il. 104.

82 M is i a g - B a c heńs ka, jw. fig. 326 .

83 To m k ow ic z: Powiat grybowski s. 12 -132." 
nego a spalonego dawnego obrazu M. B. Szkaplerznej, święconej w parafii drugim odpustem. Kult ten nie jest zbyt dawny, gdyż jeszcze w r. 1759 wielką czcią darzono tutaj obraz M. B. Bolesnej znajdujący sie w bocznym ołtarzu ${ }^{8 t}$.

Obrazy zawieszone na ścianach: 1) malowany na płótnie obraz M. B. Bolesnej z XVIII w.; 2) płaskorzeżbiony obraz M. B. Częstochowskiej z XVIII w.; 3) malowany na płótnie obraz M. B. Saletyńskiej z XIX w.; 4) oleodrukowy obraz M. B. Nieustającej Pomocy; 5) gipsowa figura Niepokalanej.

Z feretronów jeden z malowanym obrazem Serca Maryi, po drugiej stronie Serca Pana Jezusa.

Choragwie i sztandary: 1) koloru białego z malowanym na płótnie obrazem M. B. Szkaplerznej, po drugiej stronie Chrystusa Zmartwychwstałego; 2) koloru czerwonego z malowanym obrazem Serca Maryi, po drugiej stronie Serca Pana Jezusa; 3) koloru czarnego z malowanym obrazem M. B. Różańcowej, po drugiej stronie Pana Jezusa na Krzyżu.

$\mathrm{Na}$ dwu białych ornatach widnieją wizerunki Niepokalanej i Serca Maryi a na jednym z kielichów wizerunek Niepokalanej.

W Muzeum Diecezjalnym w Tarnowie znajdują się dwie figurki z pocz. XVI w. Maryi i św. Jana spod krzyża (nr inw. 187).

W Muzeum Narodowym w Krakowie pozostają; 1) obraz Ukrzyżowania z ok. 1440 r. (nr inw. 1010), przedstawiający Chrystusa Ukrzyżowanego, Longina przebijającego bok Chrystusa, setnika, św. Jana, św. Marię Magdalenę i Maryę Bolesną. Obraz przebywał kiedyś w dawnym kościele, $w$ jednym z bocznych ołtarzy ${ }^{85}$ zapewne jako kwatera dawnego ołtarza szafiastego. Należy on do wcześniejszych i czołowych pozycji sądeckiego malarstwa ${ }^{86}$; 2) fragment ołtarza (nr inw. 1012) przedstawiający Maryę Bolesną, pochodzący z tego samego czasu. Prawdopodobnie stanowi on fragment postaci zajmującej całe skrzydło tryptyku $\mathrm{z}$ analogicznym przedstawieniem. Chrystusa jako Męża Boleści ${ }^{87}$; 3) tryptyk z pocz. XVI w. ze skrzydłami (nr inw. 7784) przedstawiającymi świętych i środkową sceną - Madonny z Dzieciątkiem w otoczeniu św. Jana Chrzciciela i św. Urszuli ${ }^{88}$, Obraz ten prezentuje częsty spo-

84 Por. „Situs ecclesiae parochialis [Korzenens:s] d. 25 martii 1759 conscriptus" (w Arch. Diec. w Tarnowie).

85 ,Tertium [altare] ex parte dextra ex opposito secundi, similiter lapideum et inviolatum, cum imagine Passionis Jesu Christi". Wizyt, dek, bobowskiego z r. 1608 k. $21 \mathrm{v}$ (w Arch. Kap. Krak.).

86 Wł. Łuszczki e w i c z: Obrazy szkół cechowych polskich. Kraków 1896 s. 25 fig. 6; Tom k ow i c z: Powiat grybowski s. 131 fig. 13; K o pera: Sredniowieczne malarstwo w Polsce s. $153-155$ fig. 136; W a lick i: Sredniowieczne malarstwo polskie w XV w. s. $65,66,128$, tabl, 8 .

8i Eusz czki ewicz: Obrazy szkół cechowych s. 25 fig. 7 ; To mk ow ic z: Powiat grybowski s. 132 fig. 14; Ko p e ra: Sredniowieczne malarstwo s. 125.

88 Według protokółu wizytacji dek, bobowskiego z $r .1608$ (k. 21) kościół w K. był pod wezw. św. Jana Chrzc., według zaś „Situs ecclesiae parachialis [Korzenensis] z 1759 r." jest on już tyt. św. Urszuli z tow. 
sób przedstawiania Maryi w otoczeniu świętych jako tzw. "Santa Conversazione" ${ }^{89}$; 4) zwieńczenie tryptyku (nr inw. 7782) przedstawiające scenę Koronacji Maryi, stanowiące zapewne jedną całość konstrukcyjną z poprzednio wymienionym tryptykiem. U dołu sceny widzimy jakiegoś duchownego fundatora.

Kapliczki.i figury: 1) w Korzennej, koło kościoła znajduje się między drzewami krzyż z rzeźbioną sceną Ukrzyżowania i Maryi Bolesnej; 2) w Korzennej, przy drodze prowadzącej do Mogilna kamienna kaplica z figurą Niepokalanej; 3) w Korzennej, przy drodze prowadzącej do Jasiennej, w ogródku Michała Maciaszkạ murowana kapliczka z figurą Niepokalaneji 4) w Korzennej, na realności Andrzeja Turskiego na drewnianym krzyżu szafeczka z rzeźbioną sceną Ukrzyżowania z Maryą Bolesną; 5) w Łyczanej, koło dworu na kamiennej kolumnie kapliczka z obrazem Matki Boskiej; 6) w Niecewi, na realności Franciszka Pawlaka na brzozie wisi szafeczka ze sceną Ukrzyżowania; 7) niedaleko od poprzedniej na jesionie kapliczka z obrazem M. B. Częstochowskiej; 8) w Niecewi, na realności rodziny Swieradów kamienna kapliczka $\mathrm{z}$ oleodrukowym obrazem Maryi.

Przy kościele istnieje bractwo Wiecznego i Żywego Różańca. Parafianie uczęszczają z pielgrzymkami do Tuchowa.

\section{KOWALOWY (pow. Tarnów)}

Parafia istnieje od r. 1947. Kościól obecny pod wezwaniem Serca Maryi Panny. Kościół dawniejszy — św. Katarzyny, przeniesiony w r. 1947 z Ryglic, istniał już w XIV w.

W ołtarzu głównym umieszczony jest obraz Serca Maryi malowany na płótnie w r. 1953 przez ks. Stachonia z Nowego Sącza. W bocznym ołtarzu umieszczona została gipsowa figura Niepokalanej. Poza tym jest. mały prowizoryczny ołtarzyk M. B. Częstochowskiej. Na ścianie zawieszony jest oleodruk M. B. Nieustającej Pomocy.

Feretron posiada rzeźbę M. B. Fatimskiej wykonaną w drzewie w r. 1953 przez Stanisława Proszowskiego z Jodłowej.

Choraggwie i sztandary: 1) koloru czerwonego z malowanym obrazem M. B. Częstochowskiej, po drugiej stronie św. Stanisława Kostki; 2) koloru zielonego z malowanym obrazem M. B. Niepokalnie Poczętej, po drugiej stronie Orla Polskiego; 3) koloru zielonego z malowanym obrazem M. B. Różańcowej, po drugiej stronie św. Józefa.

Kapliczki w Kowalowach: 1) na realności Marii Legeć kapliczka z 1910 r. posiadająca figurę M. B. Różańcowej wykonaną w r. 1941; 2) na realności Antoniego Małeckiego stoi kapliczka fundowana ok.

89 毛 us z c z kiewicz: Powlat grybowski s. 131; K o p e-r a: szkół cechowych s. $13 \mathrm{n}$; T o m k o w i c z: średniowieczne malarstwo s. 185. 
1850 r. przez Tomasza Głaza, która posiada malowany na płótnie obraz M. B. Częstochowskiej.

Przy kościele istnieje bractwo Żywego Różańca. Parafianie uczęszczają na odpusty do Tuchowa.

\section{KRASNE (pow. Limanowa)}

Parafia istnieje od r. 1918. Kościół parafialny murowany pod wezwaniem Maryi Królowej Polski wzniesiony w r. $1935^{90}$.

W ołtarzu głównym pod wezwaniem Maryi Królowej Polski znajduje się cementowa polichromowana figura tego tytułu z r. 1942. W bocznym oltarzu pod wezwaniem św. Józefa znajduje się drewniana figura M. B. z Dzieciątkiem wykonana przez rzeżbiarza Samka z Bochni.

$\mathrm{Na}$ ścianie obok wielkiego ołtarza zawieszony jest malowany na desce w XIX w. obraz M. B. Częstochowskiej. Znajdował się niegdyś w kaplicy poprzedzającej kościół i darzony był żywszym kultem, o czym świadczą istniejące przy nim wota. Obecnie cześć ta ustaje. W zakrystii. wisi oleodrukowy obraz M. B. Nieustającej Pomocy. Na stalach rzeźbione są dwa obrazy, z których jeden przedstawia Maryję w koronie podającą róźaniec, drugi Maryję w koronie odbierającą serce ofiarowane Jej przez dziewczynkę.

Pięć witraży poświęcono tematyce maryjnej: Królowa Polski ze wszystkimi stanami, Bogarodzica Dziewica ze św. Wojciechen, Niepokalana ze św. Bernadettą, M. B. Częstochowska i M. B. Różańcowa.

Feretrony: 1) z malowanym na płótnie obrazem M. B. Nieustającej Pomocy, po drugiej stronie Koronacji Maryi przez Trójce Przenajświętszą; 2) z malowanym na płótnie obrazem Serca Maryi Łaskawej; 3) z drewnianą figurą Serca Maryi; 4) z gipsową figurą Niepokalanie Poczętej.

Chorągwie i sztandary: 1) koloru białego z malowanym obrazem Niepokalanej; 2) koloru białego z malowanym obrazem Maryi Królowej Niepokalanej; 3) koloru białego z malowanym obrazem M. B. Częstochowskiej; 4) koloru białego z malowanym obrazem M. B. Różańcowej; 5) koloru białego z malowanym obrazem Madonny trzymającej berło.

Na ornacie fundowanym w 1920 r. wyhaftowano obraz Maryi Niepokalanej.

Kapliczki i figury: 1) w Krasnem na realności Jana Bochenka, przy drodze do Góry św. Jana na wzniesieniu drewniana kapliczka z ołtarzykiem i rzeźbą Madonny z Dzieciątkiem z XIX w. zwaną „Panią Krasnego". Istnieje tradycja o ukazywaniu się niegdyś w tym miejscu Matki Boskiej; 2) w Krasnem na realności Franciszka Różany, w przysiółku tzw. „Lęgi" murowana kapliczka pochodząca z pocz. XIX w. posiadająca ołtarzyk z malowanym na płótnie obrazem Madonny z Dzieciątkiem.

90 Szczegółowe dane dot, budowy kościoła podaje miejscowa Kronika parafialna. 
Przy tej kapliczce odprawiają się "majówki"; 3) w Krasnem, na skrzyżowaniu dróg do Tymbarku i Słupi kamienna figura M. B. z Dzieciątkiem, fundowana przez Jana Skwarczka; 4) w Krasnem, wybudowana na realności Jana Kowacza w 1955 r. kapliczka pod wezwaniem Serca Pana Jezusa $z$ oleodrukowymi obrazami; 5) w Lasocicach, na realności Jana Zająca kamienna figura M.B. Karmiącej; 6) w Lasocicach, na realności Józefa Pająka kapliczka z XIX w. posiadająca malowane na drzewie obrazy Madonny z Dzieciątkiem i Swiętej Rodziny; 7) w Lasocicach, na realności Kunegundy Karaś kamienny postument a $w$ jednej z wnęk na miejscu starej figury Niepokalnej skradzionej w $1945 \mathrm{r}$. znajduje się nowa figura M. Boskiej. Kapliczka została wybudowana w 1846 r. po rabacji na przeproszenie Pana Boga; 8) W Słupi, na realności Marii. Sutor kapliczka z malowanym na desce obrazem Maryi z Dzieciątkiem z XIX w.; 9) w Słupi, na realności Stanisława Wąsowicza kapliczka z malowanym na drzewie obrazem M. B. z Dzieciątkiem z XIX w.

W parafii śpiewają pieśń:

„Witaj Kraśnieńska Matko Jedyna, uproś nam łaskę u Swego Syna.

Witaj, ach witaj, Niepokalana, witaj Maryjo, Matko kochana". (2 zwrotki).

W parafii istnieje bractwo Żywego Różańca i stowarzyszenie Cudownego Medalika. Wierni uczęszczają na odpusty głównie do Kalwarii Zebrzydowskiej, mniej zaś do Szczyrzyca i Dobrej.

\section{KROŚCIENKO (pow. Nowy Targ)}

Parafia istnieje od pierwszej poł. XIV w. Kościół parafialny pod wezw. Wszystkich Swiętych zbudowany prawdopodobnie w $1346 \mathrm{r}$., poszerzony nawą w $1546 \mathrm{r}$. Odpust obchodzi się w uroczystość M. B. Róźańcowej.

W rokokowym ołtarzu znajduje się obraz Madonny z Dzieciątkiem. Przy obrazie wisi ok. 50 wotów. Obecny obraz był kiedyś w feretronie i przed kilku laty został umieszczony w wielkim ołtarzu. Stanowi on kontynuacje kultu dawnego obrazu M. B. ${ }^{91}$, o którym kronika parafialna wspomina, że: "miał przyplynąć Dunajcem i cudownie zatrzymać się przed obecnym kościołem" ${ }^{92}$. Z tego tytułu kościół posiadał w $1954 \mathrm{r}$. przywilej saktuarium maryjnego.

W bocznym wczesnobarokowy ołtarzu u góry znajduje się malowany na desce obraz Niepokalanie Poczętej. W skrzydłach ołtarzyka Zaślubiny i Zwiastowanie. Dawniej w środku ołtarza znajdował się obraz Matki Boskiej z XVI w. ${ }^{93}$

91 Wizytacja dek. sądeckiego i nowotarskiego z r. 1608 k. 6: „[Altare] habet structuram parvam, cum imagine sculpta B. M. V. et colla teralibus pictis" (w Arch. Kap. Krak.).

92 Por. Kronika parafii Krościenko pod r. 1832 (na miejseu).

93 „Teka konserwat." T. 1: 1900 s. 395. 
W ostatnich latach odkryto $w$ kościele zabytkową polichromię z XIV, XV i XVI w. W partii z końca XV w. w prezbiterium znajduje się grupa Ukrzyżowania z Maryją ${ }^{94}$ a $\mathrm{w}$ nawie, $w$ polichromii sporządzonej w r. 1589 przez Jakuba Koraba z Nowego Targu, sceny z życia Chrystusa i Maryi oraz duży obraz Anny Samotrzeć ${ }^{95}$.

Wśród feretronów znajduje się jedna figura Niepokalanej z Lourdes. Na białym ornacie znajduje się wyhaftowana postać Niepokalanej.

W kaplicy parafialnej przerobionej z domu parafialnego (odprawiaja się tu główne nabożeństwa z powodu szczupłości kościoła) znajduje się w głównym ołtarzu malowany w 1922 r. przez Dziewolską obraz Matki Boskiej, a w bocznym ołtarzu obraz M. B. Nieustajaccej Pomocy.

Kapliczki i figury: 1) w kaplicy św. Rocha stojącej od XVIII w. przy ul. bł. Kingi znajduje się ołtarzyk z rzeźbą barokową M. B. Różańcowej ${ }^{90}$; 2) przy ul. Jagiellońskiej, na domu rodziny Bielów znajduje się figura drewniana Matki Boskiej; 3) na szczycie Pienin znajduje się grota bł. Kingi. Na ruinach zamku związanej z pamięcią tej błogosławionej $^{97}$ istniała pustelnia, w której znajdowała się spora ilość ludowej rzeźby i obrazków na szkle, m. in. M. Boskiej pochodzących z domów góralskich. Obiekty te spaliły się w r. 1947 wraz $z$ pustelnią.

W Muzeum Diecezjalnym w Tarnowie znajduje się pochodzący z kościoła parafialnego w Krościenku olejny obraz na desce św. Anny Samotrzeć z XVIII w. (nr inw. 931).

Przy kościele istnieje Bractwo Różańcowe. Parafianie uczęszczają z pielgrzymkami przeważnie do Częstochowy, rzadziej do Kalwarii Zebrzydowskiej.

\section{KRÓLOWA RUSKA (pow. Nowy Sącz)}

Parafia istnieje od 1946 roku. Kośció 1 parafialny pod wezwaniem Narodzenia Maryi Panny zbudowany w 1814 roku. Dawniej był to kościół grecko-katolicki.

W ołtarzu głównym znajduje się malowany na desce obraz Matki Boskiej z rękami wzniesionymi do góry i medalionem z Dzieciątkiem Jezus na piersiach - bizantyjski typ tzw. „Blachernitissy“. W owalnych medalionach po dwu stronach Maryi znajdują się głowy św. Joachima i św. Anny. W kościele są dwa małe ołtarzyki z obrazami M. B. z Dzieciątkiem oraz Narodzenia Maryi, prawdopodobnie z r. $1685^{98}$.

Feretrony: 1) malowany na desce obraz Narodzenia Maryi, po drugiej stronie, Ukoronowania Maryi; 2) malowany na płótnie obraz Niepokalanej; 3) malowany na papierze obraz Nieustającej Pomøcy.

$94 \mathrm{Szyd}$ łow ski: Powiat nowotarski fig. 415.

95 Tamże s. 358.

96 Tamże s. 359.

97 Por. St. S móls k i: Pieniny, przyroda i człowiek. Kraków 1955 s. 157 161 ryc. 47.

98 Tomkowicz: Powiat grybowski s, 132. 
Na jednym sztandarze czerwonym jest malowany na płótnie obraz M. B. z Dzieciątkiem, po drugiej stronie Serca Pana Jezusa.

Na dzwonie znajduje się wizerunek M. B. z Dzieciątkiem.

We wsi Bogusza znajduje się filialny kościół pód wezw. św. Dymitra wybudowany w $1858 \mathrm{r}$. W wielkim ołtarzu mieści się malowany na płótnie obraz Ukoronowania Maryi. W małym prowizorycznym ołtarzyku zawieszono obraz Madonny z Dzieciątkiem z 1725 r.

Kapliczki i figury: 1) w Królowej Polskiej kapliczka z malowanym na papierze obrazem Matki Boskiej. Dawniej odprawiała się tutaj msza św.; 2) w Królowej Ruskiej gipsowa figura Matki Boskiej.

Parafianie odbywają pielgrzymki do Kalwarii Zebrzydowskiej i Tuchowa.

\section{KRÓLÓWKA (pow. Bochnia)}

Parafia istnieje od drugiej poł. XIII w. Kościól parafialny pod wezw. Przemienienia Pańskiego zbudowany w $1943 \mathrm{r}$.

W kaplicy z 1875 r. pod wezw. Matki Boskiej, tworzącej całość z nowym kościołem, znajduje się ołtarz z obrazem M. B. Różańcowej malowanym pod koniec XIX w. na płótnie i drewniana figura $M$. B. z Lourdes pochodząca $\mathrm{z}$ tego samego czasu. W ołtarzu pochodzącym $\mathrm{z}$ dawnego kościoła mieści się malowany na płótnie w XVIII w. obraz Niepokalanej. Na ścianie jest zawieszony obraz M. B. Nieustającej Pomocy przywieziony tutaj w $1896 \mathrm{r}$. z Rzymu. Przy obrazie jest 15 wotów. Na ścianie nad kaplicą Różańcową zawieszony jest obraz M. B. Kalwaryjskiej malowany przez ks. Józefa Kaczmarczyka z Krakowa. Kopię sporządzono w 1939 r. do użytku Kalwarii Zebrzydowskiej, kiedy to oryginalny obraz Kalwaryjski na początku wojny byl przechowywany w jednym z domów Królówki. Na tę pamiątkę kopia obrazu Kalwaryjskiego została umieszczona $w$ tutejszym kościele.

W kaplicy Różańcowej znajduje się witraż przedstawiający M. B. Różańcową.

Feretrony: 1) z malowanym na płótnie obrazem Matki Boskiej z Dzieciątkiem z XIX w., po drugiej stronie św. Michała; 2) z rzeźbioną w drzewie figurą M. B. Różańcowej; 3) z rzeźbioną w drzewie figurą Maryi z Dzieciątkiem.

Kapliczki i figury: 1) w Królówce, na realności Józefa Goca kamienna figura z 1885 r. M.B. Niepokalanie Poczętej; 2) w Królówce tzw. "Nowy Świat”, na realności Franciszka Tworzydły figura M. B. Wspomożycielki Wiernych z początku XX w.; 3) w Królówce, na realności Jana Musa kamienna figura Matki Boskiej z Dzieciątkiem z 1906 r.; 4) w Królówce tzw. "Nowy Swiat", kamienna figura z XIX w. przedstawia Zdjęcie z krzyża; 5) w Królówce, na realności rodziny Stochlów kamienna figura M. B. Nieustającej Pomocy z 1909 r;; 6) w Królówce, 
na realności Józefa Babraja kamienna figura Niepokalanie Poczętej z 1947 r.; 7) w Królówce, na realności rodziny Miłosów kamienna figura M. B. Różańcowej z XIX w.; 8) w Królówce, na realności rodziny Golonków kamienna figura M. B. Różańcowej z 1904 r.; 9) w Królówce, na realności rodziny Komarów kamienna figura M.B. Róźańcowej; 10) w Królówce wzniesiono w 1950 roku figurę Niepokalanej jako wotum za ocalenie uchodźców z Bochni, którzy znajdowali się tutaj podczas bitwy w dniu 20 stycznia 1945 r.; 11) w Cichawce, na realności rodziny Kaczmarczyków kamienna figura M. B. Róźańcowej z 1909 r.; 12) w Cichawce, na realności Józefa Smagi kamienna figura M. B. Różańcowej z 1915 r.; 13) w Cichawce, na realności rodziny Płachtów nowsza kamienna figura M. B. Różańcowej; 14) w Soślinach, na realności rodziny Brzegowych kamienna figura M. Boskiej z Dzieciątkiem z 1888 r.

W roku 1875 założone zostało $\mathrm{w}$ parafii bractwo Różańca Wiecznego. Parafianie uczęszczają z pielgrzymkami dwa razy w roku do Kalwarii Zebrzydowskiej, na Wielki Tydzień i uroczystość Wniebowzięcia.

\section{KRUŻLOWA (pow. Nowy Sącz)}

Parafia istnieje od pierwszej poł. XIV w. Kościół parafialny pod wezwaniem Maryi Panny zbudowany w 1520 r., kilkakrotnie potem był przebudowany.

W ołtarzu głównym znajduje się malowany na desce obraz ilustrujący symboliczne narodzenie Maryi Panny. W bocznym ołtarzu znajduje się obraz M. B. Róźańcowej zastawiany malowaną kopią słynnej rzeźby "Pięknej Madonny" pochodzącej z Krużlowej. W kaplicy, w ołtarzu św. Antoniego znajduje się rzeźba M. B. z Dzieciątkiem pochodząca z 1680 r.

Kościół został polichromowany w $1520 \mathrm{r}$. W kasetonach stropu nawy są obrazy Zwiastowania i św. Anny Samotrzeć ${ }^{99}$. Na belce tęczowej grupa Ukrzyźowania z XVI w. Również na ścianie zewnętrznej pod obecnym oszalowaniem znajduje się malowana grupa Ukrzyżowania.

Feretrony: 1) z malowanym na plótnie obrazem Maryi i św. Anny, po drugiej stronie - Trójcy Swiętej; 2) z malowanym na płótnie obrazem M. B. Częstochowskiej, po drugiej stronie - P. Jezusa w cierniowej koronie; 3) z rzeźbioną $\mathrm{w}$ drzewie figurą Maryi z Dzieciątkiem; 4) z rzeźbioną $w$ drzewie figurą Niepokalanej.

Sztandary i chorągwie: 1) koloru żóltego z malowanym na płótnie obrazem M. B. Szkaplerznej, po drugiej stronie M. B. Różańcowej; 2) koloru niebieskiego z malowanym na płótnie obrazem Zwiastowania, po drugiej stronie Zesłania Ducha Swiętego; 3) koloru zielonego z malowanym obrazem Swiętej Rodziny, po drugiej stronie Przemienienia Pańskiego.

99 M is i ag - B ocheńska, jw. fig. 422 . 
Na ornacie białym wyhaftowano postać Niepokalanej. Na dzwonie z 1457 r. obok daty i napisu „o rex glorie, Veni cum pace” jedna z trzech płaskorzeźb przedstawia Madonnę z Dzieciątkiem ${ }^{\mathbf{1 0 0}}$.

W Muzeum Diecezjalnym w Tarnowie znajduje się malowany na płótnie obraz rokokowy (nr inw. 121) przedstawiający Opłakiwanie Chrystusa przez Maryję.

W Muzeum Narodowym w Krakowie znajdują się: 1) Najsłynniejsza w Polsce "Madonna Piękna" z pocz. XV w. ${ }^{101}$ Była ona niegdýs w głównym ołtarzu kościoła jako środkowa część całego tryptyku ${ }^{102}$. Póżniej została przeniesiona do ołtarza w kaplicy ${ }^{103}$, skąd w r. 1899 została zabrana do Muzeum Narodowego w Krakowie (nr inw. 10315): 2) fragment środkowej części tryptyku z XV/XVI w. przedstawiający Madonnę na półksiężycu w obecności św. Bernarda Sieneńskiego ${ }^{104}$.

Kapliczki i figury: 1) w Krużlowej, na realności Franciszka Biel.atowicza kapliczka z figurą Serca Maryi; 2) w Krużlowej Niźnej, na posiadłości Józefy Sredniawskiej drewniana kapliczka z malowanym ıa płótnie obrazem M. B. Częstochowskiej; 3) w Starej Wsi, na realności Katarzyny Tarasek kamienna figura M. B. Różańcowej z 1853 r.

Parafianie uczęszczają na odpusty do Tuchowa, Kalwarii Zebrzydowskiej, Ptaszkowej, Korzennej, Grybowa i Dębowca.

\section{KRYG (pow. Gorlice)}

Parafia istnieje od 1930 r. Kościół parafialny pod wezwaniem Królowej Polski wzniesiono w 1932 r.

W głównym ołtarzu znajduje się malowany na desce obraz Maryi Królowej Polski. W małym ołtarzyku gipsowa figura Niepokalanej. W zakrystii zawieszony jest oleodrukowy obraz M. B. Częstochowskiej. Wśród witraży jeden (w transepcie po stronie Lekcji) przedstawia Serce Maryi, drugi w oknie frontowym M. B. Częstochowską.

Feretrony: 1) z malowanym na blasze obrazem M. B. Różańcowej, po drugiej stronie Świętej Rodziny; 2) z drewnianą figurą Serca Maryi.

Chorągwie i sztandary: 1) koloru czerwonego z malowanym obrazem Królowej Polski, po drugiej stronie św. Franciszka; 2) koloru złotego z malowanym obrazem Siedmiu Boleści Maryi; po drugiej stronie św. Antoniego; 3) koloru białego z malowanym obrazem M. B. Częstochowskiej, po drugiej stronie św. Floriana; 4) koloru czarnego z malo. wanym obrazem M. B. Bolesnej, po drugiej stronie P. Jezusa w Ogrójcu.

Na białym ornacie znajduje się wizerunek Maryi Królowej Polski. Na drzwiach tabernaculum wykuto w blasze wizerunek Zwiastowania.

100 Szyd low sk i: Dzwony starodawne s, 48 ,

101 D utki ew i c z: Małopolska rzeźba średn. s. $138-139$ il. 89.

102 Wizytacja dek. bobowskiego z r. 1608 k. 152 (w Arch. Kap. Krak.).

103 Tom kow i c z: Powiat grybowski s. 139.

104 Tamże s. 140 . 
Kapliczki i figury: 1) w Krygu, na realności Wojciecha Karpia znajduje się na drzewie figurka Niepokalanej, 2) w Krygu w dolnej części jednego z krzyźów gipsowa figurka Niepokalanej ${ }_{i}$ 3) w Krygu-Ŝwiniarach, na realności rodziny Oleszkowiczów znajduje się na drzewie kapliczka ze statuą Niepokalanej.

Przy kościele istnieje Bractwo Różańcowe. Parafianie uczęszczają na odpusty do Tarnowca, Tuchowa i Dębowca.

\section{KRYNICA DOLNA (pow. Nowy Sącz)}

Parafia istnieje od 1946 roku. Kościół parafialny pod wezwaniem św. Piotra i Pawła zbudowano w 1886 r. Dawniej była tu parafia greckokatolicka. Odpust obchodzi się na uroczystość Nieustającej Pomocy.

W ołtarzu głównym znajduje się malowany na desce obraz $M$. B. Nieustającej Pomocy. W ołtarzu bocznym umieszczony jest malowany na płótnie obraz Niepokalanej.

Kościół został pomalowany w $1935 \mathrm{r}$. Jedna ze scen przedstawia Ofiarowanie w świątyni. Na ścianie umieszczone są dwa obrazy: 1) malowany na plótnie Niepokalanej z 1836 r. 2) malowany na desce obraz M. B. Nieustającej Pomocy.

Feretrony: dwa gipsowe $\mathrm{z}$ wizerunkiem Niepokalanej.

Chorągwie i sztandary: 1) koloru białego z malowanym na płótnie obrazem M. B. z Dzieciątkiem, po drugiej stronie Świętej Rodziny; 2) koloru czerwonego z malowanym na płótnie obrazem M. B. z Dzieciątkiem, po drugiej stronie świętego Biskupa; 3) koloru niebiesko-czerwonego $\mathrm{z}$ malowanym obrazem Swiętej Rodziny, po drugiej stronie św. Anny z Maryją.

W kościele znajduje się dzwon "Maryja” z wizerunkiem M. B. Nieustającej Pomocy i napisem: „Imię moje Maria. Ludu Maryi, Narodzie Polski, gdy usłyszysz głos mój, przerwij pracę, pozdrów Marię, zmów Anioł Pański, wspomnij zmarłych i poległych za wiarę i ojczyznę: Powołały mnie do życia szlachetne i ofiarne serca parafian".

Przy kościele istnieją tzw. "Róże". Parafianie uczęszczają najchętniej do figury M. B. Niepokalanej w parku Krynicy-Zdroju, szczególnie na procesję odbywającą się tam $w$ ostatnią niedzielę maja.

\section{KRYNICA-ZDRÓJ (pow. Nowy Sącz)}

Parafia istnieje od 1904 roku. Kościół pod wezwaniem Wniebowzięcia Maryi Panny wzniesiony w $1892 \mathrm{r}$.

W ołtarzu głównym, fundowanym przez krynickiego kuracjusza J. Rakowskiego z Hermanowic, znajduje się kopia Madonny Murilla wykonana w 1892 r. przez art. mal. Feliksa Franica. W czterech bocznych ołtarzach znajdują się: 1) malowany na płótnie obraz Niepokalanej; 2) malowany na drzewie obraz M. B. Nieustającej Pomocy z 1912 r.; 
3) w ołtarzu św. Józefa malowany w 1924 r. przez art. mal. Rutkowskiego obraz M. B. Częstochowskiej jako wotum pierwszej wspólnej pielgrzymki parafii do Częstochowy; 4) w ołtarzu P. Jezusa Ulkrzyżowanego malowany na płótnie w $1953 \mathrm{r}$. obraz M. B. Bolesnej.

W prezbiterium znajduje się obraz Ofiarowania Maryi Panny art. malarza Le Sumer z 1916 r. ofiarowany w 1939 r. przez Kaz. Bergsona z Warszawy.

Feretrony: 1) z rzeźbioną $w$ drzewie figurą $M$. B. Różańcowej; 2) $\mathrm{z}$ rzeźbioną $\mathrm{w}$ drzewie figurą $\mathrm{M} . \mathrm{B}$. $\mathrm{z}$ Lourdes.

Chorągwie i sztandary: 1) koloru biało-czerwonego z malowanym obrazem M. B. Częstochowskiej, po drugiej stronie Orła Białego; 2) koloru czerwonego z malowanym obrazem M. B. Różańcowej, po druyiej stronie Serca Pana Jezusa; 3) koloru białego $\mathrm{z}$ malowanym obrazem Serca Maryi, po drugiej stronie św. Franciszka; 4) koloru białego z malowanym obrazem Niepokalanej, po drugiej stronie Serca Pana Jezusa.

Ornaty: 1) koloru białego $\mathrm{z}$ haftowanym obrazem M. B. Czestochowskiej; 2) koloru białego z haftowanym obrazem Niepokalanej; 3) koloru białego $\mathrm{z}$ haftowanym obrazem Serca Maryi.

$\mathrm{Na}$ jednym z dzwonów sprawionym w $1953 \mathrm{r}$. znajduje się płaskorzeźba "Matki Boskiej Krynickiej”, herb Krynicy-Zdroju oraz napis: „Przeczystej Dziewicy. Królowo Krynickich Zdrojów módl się za swoje dzieci. Fundowany przez parafian i kuracjuszy“.

Kościoły i kaplice: 1) w kościele w Słotwinach znajduje się w oltarzu malowany na piótnie obraz M. B. Nieustającej Pomocy oíiarowany przez p. Kozieniową z Krynicy; 2) w kaplicy w Parku (pierwszy kościół w Krynicy) w bocznym ołtarzu znajduje się malowany na desce z XIX w. obraz M. B. Częstochowskiej; 3) przy ul. Kraszewskiego stoi wybudowany w 1938 r. "Sierociniec" z kaplicą i obrazem M. B. Częstochowskiej; 4) przy ul. Dąbrowskiego w "Ochronce" pod wezw. Niepokalanej w bocznym ołtarzu jest sporządzona z masy w 1936 r. figura Niepokalanej. W ogrodzie przy Ochronce również stoi figura Niepokalanej; 5) przy ul. Pułaskiego, w domu SS. Elżbietanek w kaplicy znajduje się obraz M. B. Częstochowskiej; 6) w Domu Wypoczynkowym KUL jest także obraz M. B. Częstochowskiej; 7) przy ul. Kościelnej, w "Domu kościelnym Miłosierdzia" znajduje się w kaplicy obraz Niepokalanej.

Kapliczki i figury: 1) na cmentarzu kościelnym, od północnej jego strony znajduje się tigura Matki Boskiej ufundowana w 1896 r. przez rodzinę Klimczyków z Krynicy a wykonana w kamieniu przez T. Błotnickiego; 2) na placu kościelnym przed plebanią jest kamienna figura Niepokalanej; 3) koło nowej szkoły przy drodze stoi figura Matki Boskiej przeniesiona tutaj z Parku Skórczewskiego; 4) przy ul. Pułaskiego znajdują się dwie figury Matki Boskiej.

W parku nad Głównym Zdrojem, na stoku góry znajduje się wznie. siona w 1864 r. figura M. B. Niepokalanie Poczęlej, otaczana wielką 
czcią, szczególnie przez kuracjuszy. Woda czerpana z pobliskiego źródła uważana jest za cudowną i pomagającą na dolegliwości ciała i ducha. U podstaw powstania tej figury tkwi legenda o pasterce, która ongiś prosiła Maryję o pomoc dla zranionego śmiertelnie, wracającego $\mathrm{z}$ wojennej wyprawy umiłowanego rycerza. Zobaczyła ona Maryje wskazującą na źródło i mówiącą "obmyj tą wodą rany rycerza a żyć będzie". Artur Grottger wykonał rysunek postaci Maryi, według którego wykuto opisywaną figurę Matki Boskiej. Kulminacyjnym punktem nabożeństwa jest procesja odbywająca się co roku w ostatnią niedzielę maja wieczorem $\mathrm{z}$ kościoła parafialnego do figury $\mathrm{w}$ parku. Imponującego efektu dodają światła niesione przez wielotysięczne rzesze parafian i kuracjuszy ${ }^{105}$. Figura posiadała w 1954 r. przywilej sanktuarium maryjnego.

W Krynicy przebywa, maluje i sprzedaje obrazki egzotyczny Nikifor zwący się Janem Matejką. W ikonografii tych dziwnych obrazków jedno z pierwszych miejsc zajmuje tematyka maryjna. Wśród niej znaleźć można niespotykane dotychczas sceny pełne swoistego apokryfizmu (np. Chrystus i Maryja w łodzi, Chrystus Bolesny ukazujący się Maryi z kielichem, Opłakiwanie wielkopiątkowego Grobu Chrystusa przez Maryję itp.) oraz mistycyzmu ${ }^{106}$.

Istnieją dwie pieśni do Matki Boskiej Krynickiej:

1) „Pokłon Przeczystej Dziewicy. Postać Jej biała, świetlana, jaśnieje w parku Krynicy.

To Matka Nasza Kochana". (6 zwrotek).

2) "Krynicka Pani.

Na górze posąg Krynickiej Matki, z daleka nam widnieje.

Do stóp Jej garną się ufnie dziatki, do tej, co dobroć sieje". (7 zwrotek).

W parafii znajduje się bractwo Różańca Świętego.

\section{KRZYŻ (pow. Tarnów)}

Parafia istnieje od 1925 r. Kościół pod wezwaniem Podwyższenia Krzyża świętego wzniesiono w 1909 r.

W ołtarzu głównym, pod obrazem Ukrzyżowania znajduje się malowany na płótnie obraz M. B. Bolesnej; w bocznym oltarzu wisi malowany na desce obraz M. B. Nieustającej Pomocy. Przy obrazie jest ok.

105 Por. druk ulotny bez tyt. m. r. podający dzieje kultu figury „Matki Boskiej Krynickiej”.

106 Por. Ks. Wł. Smoleń: Otwarcie wystawy Zbiorów Sztuki Kościelnej Katolickiego Uniwersytetu Lubelskiego. „Archiwa, Bibliot., Muzea kośc.” T. 1: 1960 z. 2 s. $169-170$. 
100 wotów. W kaplicy na ścianie zawieszony jest malowany na płótnie w XIX w. obraz M. B. Różańcowej.

Feretrony: 1) z malowanym obrazem M. B. Nieustającej Pomocy, po drugiej stronie św. Józefa; 2) z drewnianą rzeźbą Niepokalanej; 3) inny mniejszy feretron $z$ drewnianą rzeźbą Niepokalanej.

$\mathrm{Na}$ jednym ze sztandarów koloru białego wyhaftowano obraz M. B. Częstochowskiej, po drugiej stronie Orła Białego.

Kapliczki i figury: 1) na parceli gromadzkiej obok remizy strażackiej stoi kamienna figura Niepokalanej wzniesiona w połowie XIX w. na miejscu dawnej karczmy. Według opowiadania miejscowej ludności od czasu postawienia figury przestały nawiedzać tę miejscowość nieszczęścia i klęski żywiołowe. Figura ta jest widomą pozostałością patronowania Maryi Niepokalanej nad żywym ruchem abstynenckim w diecezji tarnowskiej $\mathrm{w}$ polowie XIX wieku; 2) na parceli rodziny Wątrobów obok cmentarza znajduje się krzyż wzniesiony - według podania na wspólnej mogile poległych w potyczce ze Szwedami w $1656 \mathrm{r}$. Na krzyżu znajduje się również figurka Niepokalanej; 3) przy szosie do Tarnowa znajduje się kapliczka, z której skradziono figurkę św. Antoniego a na jej miejscu umieszczono obecnie obraz Matki Boskiej; 4) obok pałacu, na terenie dawnego dworu, wzniesiono podczas ostatniej wojny grotę z figurą Niepokalanej.

Przy kościele istnieje Bractwo Różańcowe. Parafianie uczęszczają z pielgrzymkami najczęściej do Tuchowa, rzadziej do Kalwarii Zebrzydowskiej, Częstochowy i Odporyszowa.

\section{KRZYŻANOWICE (pow. Bochnia)}

Parafia istnieje od drugiej poł. XIIl w. Kościół drewniany pobernardyński z Bochni pod wezwaniem św. Joachima został przeniesiony tutaj w 1794 r. ${ }^{107}$

W oltarzu bocznym poświęconym Maryi znajduje się malowany na plótnie w XIX w. obraz Matki Boskiej. W tym samym ołtarzu umieszczono nowszy obraz M. B. Różańcowej.

W polichromii z $1876 \mathrm{r}$. znajduje się na stropie obraz Niepokalanej.

$\mathrm{Na}$ ścianie są zawieszone dwa obrazy, malowany na desce obraz Niepokalanej oraz malowany na płótnie obraz "Gwiazdy Morza“.

Feretrony: 1) z malowanym na płótnie obrazem "Gwiazdy Morza", po drugiej stronie św. Joachima; 2) $\mathrm{z}$ malowanym $\mathrm{w}$ XIX w. na płótnie obrazem M. B. Różańcowej, po drugiej stronie M. B. z Dzieciątkiem w otoczeniu dzieci; 3) z rzeźbioną figurą M. B. z Lourdes; 4) z rzeźbioną fi-

107 Dutkiewicz: Powiat bocheński. W: „Katalog zabytków sztuki w Polsce". T. 1 , s. 47 . 
gurą M.B. z Dzieciątkiem; 5) z rzeźbioną figurą Serca Maryi; 6) z rzeźbioną figurą M. B. Anielskiej.

Choraggwie i sztandary: 1) koloru czerwonego z malowanym obrazem M. B. Częstochowskiej, po drugiej stronie Serca Pana Jezusa; 2) koloru czerwonego z malowanym obrazem M. B. Częstochowskiej, po drugiej stronie św. Józefa; 3) koloru niebieskiego z malowanym obrazem Niepokalanej, po drugiej stronie św. Józefa.

Na kielichu umieszczono na stopce wykonany w emalii wizerunek Niepokalanej.

$\mathrm{Na}$ cmentarzu grzebalnym znajduje się kaplica mszalna $\mathrm{z}$ końca XIX w. wzniesiona nad grobowcem właścicieli dóbr $\mathrm{w}$ Proszówkach a w niej ołtarzyk $z$ obrazem Niepokalanej.

W Krzyżanowicach, na realności rodziny Stopów znajduje się rzeźbiona $\mathrm{w}$ kamieniu figura przedstawiająca Koronację Maryi.

W parafii istnieje zwyczaj śpiewania podczas mszy weselnej pieśni opiewającej objawienie się M. B. Bocheńskiej.

Na odpusty parafianie uczeszczają do Okulic i Bochni. Do Kalwarii Zebrzydowskiej udają się na cały tydzień przed 15 sierpnia. Często też jeżdżą do Częstochowy.

\section{KSIAzZNICA (pow. Mielec)}

Parafia istnieje od drugiej poł. XIII w. Kościół pod wezwaniem św. Jana Chrzciciela wybudowano w 1927 r.

W ołtarzu głównym znajciuje się malowany na blasze obraz Matki Boskiej trzymającej $w$ ręku lilię. W trzech ołtarzach bocznych znajdują się: figura gipsowa Niepokalanej, malowany na desce obraz.M. B. Bolesnej i malowany obraz Wniebowziętej.

Na ścianach znajdują się obrazy: 1) M. B. z Dzieciątkiem; 2) oleodrukowy M.'B. Częstochowskiej; 3) malowany na desce M. B. z Dzieciątkiem.

Feretrony: 1) z malowanym obrazem M. B. Częstochowskiej, po drugiej stronie Madonny z Dzieciątkiem; 2) z malowanym w 1930 r. we Włoszech obrazem M. B. z Dzieciątkiem; 3) z malowanym na desce obrazem Niepokalanej.

Chorągwie i sztandary: 1) koloru niebieskiego z malowanym obrazem Niepokalanej; 2) koloru białego z malowanym obrazem M. B. Częstochowskiej; 3) koloru białego z malowanym obrazem Serca Maryi; 4) koloru białego z malowanym obrazem M. B. Różańcowej.

W Woli Mieleckiej znajduje się mszalna kaplica pod wezw. Narodzenia. M. B. z 1905 r. z ołtarzykiem i obrazem Matki Boskiej. Na ścianie wisi oleodrukowy obraz M. Boskiej. 
Kapliczki i figury: 1) w Goleszowie znajduje się kapliczka ufundowana w 1831 r. przez Franciszka i Zofię Pieprzny a w niej obok figury Chrystusa Frasobliwego, rzeźbionego w drzewie obraz M. B. Czestochowskiej. Do kaplicy tej odbywaja się procesje w dni krzyżowe; 2) w Podleszanach kamienna figura Niepolalanej fundowana w 1933 r. przez Alfonsa i Agnieszkę Kaniów.

W parafii istnieje Bractwo Różańca świętego. Wierni uczęszczają z pielgrzymkami do Częstochowy, Leżajska i Dzikowca.

\section{KUPNO (pow. Kolbuszowa)}

Parafia istnieje od $1919 \mathrm{r}$. W tym też roku zbudowano kościół parafialny pod wezwaniem św. Jana Chrzciciela. Od r. 1955 obchodzi się drugi odpust na uroczystość Królowej Nieba i Ziemi.

W wielkim ołtarzu znajduje się rzeźbiona w drzewie figura z XVIII w., przeniesiona tutaj z macierzystego kościoła w Kolbuszowej przedstawiająca postać Niepokalanej. Figura darzona jest specjalnym kultem i dlatego kościół posiadał w $1954 \mathrm{r}$. przywilej sanktuarium maryjnego.

W bocznym ołtarzu znajduje sie obraz M. B. Róźańcowej. Nad wielkimi drzwiami u wejścia do kościoła widnieje duża figura Niepokalanej.

Feretrony: 1) z malowanym na papierze obrazem Serca Maryi, po drugiej stronie Serca Pana Jezusa; 2) z malowanym na desce obrazem M. B. Szkaplerznej, po drugiej stronie św. Józefa; 3) z malowanym na papierze obrazem Nieustającej Pomocy, po drugiej strronie św. Alojzego; 4) z figurą Niepokalanej.

Sztandary i chorągwie: 1) koloru zielonego z malowanym obrazem Serca Maryi, po drugiej stronie Serca Pana Jezusa; 2) koloru białego z malowanym obrazem M. B. z Dzieciątkiem, po drugiej stronie św. Franciszka; 3) koloru różowego z malowanym obrazem M. B. Częstochowskiej, po drugiej stronie Serca Pana Jezusa.

Na białym ornacie wyhaftowano postać Niepokalanej. Na kielichu znajcluje się postać M. Boskiej a w monstrancji figurka Niepokalanej.

$\mathrm{Na}$ terenie parafii znajduje się jedna figura kamienna Matki Boskiej $\mathrm{z}$ początku XX w.

Parafianie śpiewają dwuzwrotkową pieśń:

"Ty, któraś sobie tron u nas obrała, by nas wspomagać $w$ życia czas;

wierzymy, Matko, żeś nas pokochała

i. nie porzucisz nigdy nas.

Byłaś nam źródłem wiary i mestwa, zawsześ nas strzegła spojrzeniem swym;

w udrękach cierpień $i \mathrm{w}$ dniach zwycięstwa -

Týs nam Królową, my ludem Twym". 
Przy kościele istnieje bractwo Różańca ŝw., Szkaplerza oraz stowarzyszenie Wstrzemięźliwości, któremu patronuje Maryja Niepokalana. W 1956 r. zaprowadzona została Nieustająca Nowenna M. B.

Od dawna opowiadali sobie ludzie, że gdy dla figury Niepokalanej uwaźanej za cudowną wybudowany zostanie nowy kościól, Polska odzyska niepodległość. Ludność uważa, że ta przepowiednia spełniła się po wybudowaniu obecnego kościoła.

Parafianie uczęszczają z pielgrzymkami do Leżajska, chociaż także swoją figurę Matki Boskiej uważają za łaskami słynącą.

C. d. $n$. 